\title{
Using the Concepts of Hermeneutical Injustice and Ideology to Explain the Stability of Ancient Egypt During the Middle Kingdom
}

\author{
Zeyad El Nabolsy ${ }^{1,2}$
}

\begin{abstract}
This paper argues that the relative stability of ancient Egyptian society during the Middle Kingdom (c.2055 - 1650 BC) can in part be explained by referring to the phenomenon of hermeneutical injustice, i.e., the manner in which imbalances in socio-economic power are causally correlated with imbalances in the conceptual scheme through which people attempt to interpret their social reality and assert their interests in light of their interpretations. The court literature of the Middle Kingdom is analyzed using the concepts of hermeneutical injustice and ideology. It is argued that while it is true that there was room for maneuver and for internal critique, the efficacy of internal critique was hindered by the structure of the intellectual discourse of Middle Kingdom Egypt. This intellectual discourse was suitable for the interpretation of social reality in a way that allowed the elites to assert their interests, but it was not suitable for the interpretation of social reality in a way that accorded with the interests of the exploited peasantry.
\end{abstract}

\section{1 | INTRODUCTION}

One of the factors that can contribute to explaining the relative stability of ancient Egyptian society during the Middle Kingdom is the manner in which the conceptual tools that were available for the interpretation of social reality in ancient Egyptian society during the Middle Kingdom were structurally biased in a way that accorded with the interests of the ruling elite. While the focus of this paper is on the ideational factors which can contribute to explaining the relative stability of ancient Egyptian society during the Middle Kingdom, one should not deny that there are other factors that can be invoked to explain this relative stability. Geographical factors such as the "caging effect" that the Nile basin had on the population (Manning, 2013), and the relative security afforded by the deserts in the east and the west of the Nile basin (Hill, Jones, \& Morales, 2013, p. 16), are significant factors that should not be discounted. Hence, the purpose of this paper is not to discount geographical and economic factors. Instead the

\footnotetext{
${ }^{1}$ Zeyad el Nabolsy is a PhD student at the Africana Studies and Research Center, Cornell University. He can be contacted via email at: ze44@cornell.edu ${ }^{2}$ This paper has benefitted tremendously from suggestions made by Christopher M. Monroe, as well as the comments and suggestions that were made by anonymous reviewers for The Journal of Historical Sociology. I also wish to acknowledge Michelle Kosch's encouragement of my rather unorthodox engagement with the concept of hermeneutical injustice, which eventually led to this paper.
} 
aim is to bring attention to another contributing explanatory factor that has not received the same level of interest. I argue that if we critically examine the court literature that was produced during the Middle Kingdom, especially the court literature which was philosophical in nature, e.g., The Tale of the Eloquent Peasant, The Teachings of the Vizier Ptahhotep, etc., we can recognize the manner in which the conceptual framework which was developed by elites - and the scribes who worked on their behalf - did not allow the most exploited members of ancient Egyptian society to interpret social reality in a manner that accorded with their interests (i.e., ending their exploitation, developing alternative solutions to the co-ordination problem which every society faces, and developing an adequate internal or immanent critique of the hegemonic ideas of their ruling class).

In this paper I argue that the relative stability of ancient Egyptian society during the Middle Kingdom (c.2055 - $1650 \mathrm{BC}$ ) can in part be explained by referring to the phenomenon of hermeneutical injustice, i.e., the manner in which imbalances in socio-economic power are causally related to imbalances in the conceptual scheme through which people attempt to interpret their social reality and assert their interests in light of their interpretations. I argue that we can draw on Miranda Fricker's concept of hermeneutical injustice along with a variation of the concept of ideology in order to explain the absence of signs of dissent in the court literature of the Middle Kingdom, and in order to explain the relative stability of ancient Egyptian society during the Middle Kingdom. ${ }^{1}$ Fricker defines hermeneutical injustice as "the injustice of having some significant area of one's social experience obscured from collective understanding owing to a structural identity prejudice" in the conceptual resources which are used in the interpretation of social reality (Fricker, 2007, p. 155). ${ }^{2}$ The qualification "owing to a structural identity prejudice" is meant to indicate the fact that this injustice is inflicted on people in virtue of their membership of specific social groups. Fricker's main point is that differences in social power in a given socially stratified society, stratified that is by class, or political status, or gender, or race, or a combination of such categories, influence the set of conceptual tools through which people structure, identify, and analyze their social experiences. ${ }^{3}$ The skewing effect takes place by ensuring that the conceptual resources (and this is what Fricker means by "collective hermeneutical resources") through which marginalized groups of people come to understand their social reality are not optimally suited for the assertion of their interests vis-à-vis their exploiters. As Fricker puts it: "relations of unequal power can skew shared hermeneutical resources so that the powerful tend to have appropriate understandings of their experiences ready to draw on as they make sense of their social experiences, whereas the powerless are more likely to find themselves having some social experiences through a glass darkly, with at best ill-fitted meanings to draw on to render them intelligible" (Fricker, 2007, p. 148). This is not to deny that the oppressed are able to formulate "counter-discourses", however, we must explore the extent to which this capacity is conditioned by other factors, such as the extent of the power of the ruling elite in a given society, as well as the amenability of the dominant conceptual structures to internal or immanent critique.

I will focus on attempting to explain the relative stability of ancient Egyptian society by analyzing textual evidence from the Middle Kingdom using the concept of hermeneutical injustice and the concept of ideology. More specifically, I will focus on analyzing the court literature of the Middle Kingdom. The main reason for doing so is that the court literature of the Middle Kingdom, and specifically that of the Twelfth Dynasty (c.1985 - 1773 BC) is more discursive and more clearly argumentative in structure (i.e., arguing about how political power should be wielded and to what end it should be wielded) than the literature of previous periods (Assmann, 2002, p. 118). As Jan Assmann has argued, the fact that the kings of the Twelfth Dynasty came into power after a period of decentralization and instability meant that they "were in a fundamentally different position [in comparison to their predecessors during the Old Kingdom]. They did not rule with a 'literocracy' of educated officials over an illiterate mass but had to assert themselves against a largely literate and economically and militarily powerful aristocracy of nomarchs, magnates, and patrons with all their wide ranging-clans and adherents" (Assmann, 2002, p. 118). For the centralized rule that had obtained during the Old Kingdom (c. 2690 - 2180 BC), was eroded by the rise of elite families who competed with the royal family for political power and control. The rise of elite families during the later era of the Old Kingdom is reflected in the fact that the boundary between the royal family and non-royal elite families was undermined during the Fifth and Sixth Dynasties, where a new policy was instituted that allowed 
daughters in the royal family to marry non-royal officials (Bárta, 2013, p. 276). This has been interpreted by Egyptologists as a sign of the relative weakening of the position of the king in relation to the elite families. During this period, we can observe a weakening of the ties of dependence between the provincial elites and the king in his capital. Provincial administrators began to develop power bases in their nomes (provincial administrative units). ${ }^{4}$ There were also structural economic changes, since instead of relying on the redistribution of resources from the royal residence; the provincial elites could now directly access the surplus generated in the provinces (Seidlmayer, 2000, p. 121). There was also an attempt to replicate court culture in the provinces by importing iconographic patterns and models from the court. This was an important development, especially when we consider that "until well into the 5th Dynasty, nothing of the cultural achievements that attest to the grandeur of the Old Kingdom was to be seen outside the Memphite region" (Seidlmayer, 2000, p. 120). Moreover, it demonstrates that the non-royal provincial elites could draw on enough of the surplus to be able to attract specialized craftsman and ritualists. These developments eventually led to the collapse of centralized authority and ushered in the period known as the First Intermediate Period (c.2180-2055 BC).

The First Intermediate Period is often characterized as a period when local rulers, who now could no longer rely on the legitimacy which they derived from their relation to the monarchy, became self-conscious about the need to legitimize their power (Seidlmayer, 2000, p. 133). This concern with questions of legitimacy manifests itself to an even a greater degree with the reassertion of centralized rule during the Middle Kingdom. During the Middle Kingdom, we encounter expressions of the ideal state in literature for the first time in ancient Egypt (Manning, 2013, p. 74). The First Intermediate Period was a traumatic experience (from the standpoint of the centralized state), and it led to a fundamental rethinking of Egyptian culture (Oppenheim, 2015, pp. 4-7). On the one hand, the phenomenon that is often referred to as the "democratization of the afterlife" took place during the First Intermediate Period; this led to the extension of the Osiris concept to non-royals, when prior to this only the king could be resurrected as Osiris after his death (Bárta, 2013, p. 268). ${ }^{5}$ On the other hand, the kings of the Twelfth Dynasty reformulated the basis of kingship, and attempted to emphasize the exclusivity of the figure of the king in other ways. During the Middle Kingdom there was an increased emphasis on the king's "election" by a god (Hornung, 1982, p. 193). The reformulation of the basis of kingship was successful in so far as the Middle Kingdom was characterized by "great political stability", especially under the Twelfth Dynasty (Grajetzki, 2006, p. 64), and by the existence of a highly centralized state (Grajetzki, 2006, pp. 141-142). The rulers of the Twelfth Dynasty were successful in curbing the ambitions of the provincial elite and in reintegrating them around the court. ${ }^{6}$

The important point is that the rulers of the Twelfth Dynasty had to legitimate their rule using discursive means in a context where prior norms had been put into question (R. David, 2002, p. 140). I would argue that it is exactly under such conditions that one would expect an explicit philosophical discourse to emerge. ${ }^{7}$ If we bring to bear G. W. F. Hegel's account of the historical function of philosophy, we can make sense of this phenomenon. This is rather ironic, because Hegel himself did not think much of Egyptian thought, which he believed did not amount to "philosophy proper" (Lampert, 1995). Nonetheless he does provide us with a useful theoretical framework that supplements Assmann's remarks on Middle Kingdom court literature. For according to Hegel, philosophical discourse comes to have a prominent role to play whenever there is a crisis in relation to the legitimacy of given standards of normative justification, and according to Assmann, such a crisis took place in the wake of the First Intermediate Period (c.2180-2055 BC). On this view, philosophical discourse attempts to clarify what is at stake by making explicit the normative standards whose legitimacy is being questioned and attempts to lay out as explicitly as possible the consequences of abandoning or endorsing them. Hegel thinks that non-philosophical discourse resorts to normative standards that are not made explicit: "Healthy human understanding possesses the modes of thought, maxims, and judgments of its time, the thought-determinations of which dominate it without it being conscious thereof" (Hegel, 1995, p. 379). However, when a crisis emerges and the normative standards themselves come into question, philosophical discourse becomes necessary. As Peter Berger and Stanley Pullberg have argued, moments of crisis can lead to moments of de-reification, "bringing forth doubt and sceptisim concerning everything that had previously been taken for granted" (Berger \& Pullberg, 1965, p. 209). Berger and Pullberg mention ancient 
Egypt as a society where such a crisis occurred, but they do not specify when it occurred. We can further specify their empirical example by pointing to the First Intermediate Period and its aftermath.

Hegel uses the example of Socrates' relationship to Athenian culture to illustrate this point. He thinks that Socrates comes to have a role to play because at least some of the Athenians have lost faith in their institutions and laws, i.e., the disputes are no longer about whether for example certain acts are just or unjust according to the laws of the city, but rather about whether the laws of the city themselves are just, and about what justice is (Hegel, 1995, pp. 387-390). We can think of the situation facing the kings of the Twelfth Dynasty (and the elites around the court) as a situation where philosophy had a prominent role to play in re-fashioning and re-asserting norms about legitimacy (Karenga, 2004, p. 56). In analyzing ancient Egyptian philosophical discourse, we can deploy the broad definition of philosophy that is used by Chike Jeffers in his analysis of The Tale of the Eloquent Peasant qua philosophical text. Jeffers defines philosophy as "the activity of raising and seeking to answer, in a reflective and critical fashion, fundamental questions about the nature and value of things, about how we gain knowledge, and about how we ought to live our lives" (Jeffers, 2013, p. 421).

In fact, when historians of philosophy have attempted to dispel the myth, which Hegel played a key role in constructing, that there was no philosophy in ancient Egypt, they have turned to Middle Kingdom texts such as The Teachings of the Vizier Ptahhotep, The Tale of the Eloquent Peasant, and The Dialogue of a Man with his Soul in order to show that there was in fact philosophy in ancient Egypt (Graness, 2016). ${ }^{8}$ We should also recognize that a portion of the court literature of the Middle Kingdom came to be regarded as comprising the "classical corpus" during later periods of Egyptian history (Baines \& Yoffee, 1998; Callender, 2000). Nevertheless, one should distinguish between an "educational corpus" and a broader "known literary corpus" (Parkinson, 2002, p. 54), and some of the texts that I look at such as The Tale of the Eloquent Peasant were not part of the educational corpus, but were listed in Ramessid literary letters (Parkinson, 2002, p. 54). However, as Parkinson argues, "the survival of any manuscript suggests a degree of prestige, so that one cannot draw conclusions about the unpopular (or subversive) character of an individual poem from paucity of copies" (Parkinson, 2002, p. 53). Hence, we cannot make direct inferences about lack of popularity from the exclusion of The Tale of the Eloquent Peasant (and other texts) from the educational corpus in later periods. While analyzing texts such as The Tale of the Eloquent Peasant can probably provide us with important insights into the models of justice and order that were adhered to in later periods of Egyptian history, we cannot make strong claims about the influence of such texts on later periods of Egyptian intellectual history, without analyzing in detail the historical reception of those texts, ${ }^{9}$ a topic which will not be pursued in this essay.

Furthermore, I will analyze the manner in which religious discourse was used to justify relations of exploitation. ${ }^{10}$ I will show that while exploitative social relations were often presented in a religious form which obscured their exploitative nature, it would nonetheless be incorrect to think that the ancient Egyptian ruling elites were incapable of representing social relations in a discursive form that allowed them to articulate their interests relatively clearly. That they were able to do so is evidenced by the genre of "instructions for kings", e.g., The Teaching of King Amenemhat, The Teaching for Merikare, as well as by texts such as The Tale of the Eloquent Peasant. Hence, I argue that there is an asymmetry involved in the manner in which social relations were presented to the non-elites in a religious form that obscured exploitative relations and the manner in which those very same relations were sometimes presented to elites (within the discourse of high culture) in what we can describe as a relatively "non-mystified" form (i.e., in a way animated by "political realism"). For the elites had to be able to adjust to problems that emerged from the unequal distribution of wealth and power in a way that preserved their exploitative position vis-à-vis the peasantry. To this end, I argue that they developed concepts for interpreting social reality in a manner that allowed them to act rationally on their own interests. ${ }^{11}$ This is not to say that there is no religious discourse in texts such as The Teaching for Merikare. In fact, there is quite a lot of religious discourse in The Teaching for Merikare and The Teaching of King Amenemhat (Langer, 2015, p. 66). However, the existence of such religious discourse does not undermine the "political realism" which animates The Teaching for Merikare, for example. As Christian Langer has argued, this text is essentially a manual for social control, whose clarity and 
political realism allows one to compare it with Machiavelli's II Principe (Langer, 2015). Moreover, the fact that the ancient Egyptian elites (and the scribes who operated the Egyptian state bureaucracy) had a virtual monopoly on literacy, with only about $1 \%$ of the population being literate (Robins, 1993, p. 13), ${ }^{12}$ and a monopoly on the elaboration of concepts for interpreting social reality in textual form, meant that those concepts were more adequate for expressing their own interests as opposed to the interests of the peasantry. ${ }^{13}$

My starting point is the assumption that what needs explaining is how a society that was based on relatively transparent relations of exploitation could have stabilized itself for long periods of time (Baines \& Yoffee, 1998; Moreno Garcia, 2013; Zingarelli, 2015). By 'transparent relations of exploitation', I mean to refer to the extraction of surplus by the members of the ruling elite using direct methods such as taxation (or rent) and corvée labor. For example, Bruce G. Trigger argues that in ancient Egypt, "the only significant economic link between rural and urban centers. . . tended to be payments of rent and taxes and the performance of corvées by peasants. The transfer of food surpluses from the countryside to urban centers took place principally in terms of appropriative rather than commercial mechanisms" [my emphasis] (Trigger, 1993, p. 11). I deliberately refrain from describing the means of exploitation in this context as "coercive means", for coercion, while undoubtedly important, cannot by itself explain the stability of those relations of exploitation. One cannot deny that those who evaded their duties, e.g., corvée labour, were subject to coercive measures. For example, some evidence seems to suggest that men who evaded corvée labour were punished through the imprisonment of their wives and children (Lorton, 1977, p. 17; Trigger, 2003, p. 237; Muhs, 2016, p. 67). Moreover, severe physical punishments were inflicted for some fiscal crimes against the state (Trigger, 2003, p. 230). ${ }^{14}$ Nonetheless, Egyptologists have been puzzled by the fact that in general "coercive state mechanisms, such as police, were conspicuous by their absence" (Malek, 2000, p. 101). Hence, coercion by itself is not sufficient to explain the relative stability of the ancient Egyptian state. Moreover, we must not forget that the coercive capacity of ancient states was in general inferior to the coercive capacities of modern states (Grajetzki, 2006, p. 142; Trigger, 2003, p. 195). The issue then becomes whether we can explain the fact that revolts by peasants in ancient Egypt were relatively rare, despite the fact that exploitative relations were relatively transparent. Indeed, there is little evidence of revolts in ancient Egypt before the first millennium B.C. (Manning, 2013, p. 84), and it seems that "internal dissent was minimal, and support for the system was genuine and widespread" (Malek, 2000, pp. 100-101). ${ }^{15}$

Samir Amin argues that societies that can be characterized by the dominance of what he calls "the tributary mode of production" are characterized by "the transparency of relationships of exploitation" (Amin, 2009, p. 111). ${ }^{16}$ This transparency in relations of exploitation is a function of a more general transparency of economic phenomena. ${ }^{17}$ Note that the transparency thesis can be used to explain a rather puzzling phenomenon, namely the nonexistence of evidence for any kind of economic science in ancient Egypt and Mesopotamia, which is intriguing given the existence of very well-developed records and record keeping techniques, especially in Mesopotamia (Baines \& Yoffee, 1998, p. 213; Carmona \& Ezzamel, 2007, p. 196). One can argue that a science becomes necessary only when a certain set of phenomena becomes sufficiently opaque (Amin, 2009, p. 95). ${ }^{18}$ However, it must be made clear that transparency does not imply a lack of complexity. Hence, the claim is not that the ancient Egyptian economy during the Middle Kingdom (c. 2055-1650 BC) was somehow simple; rather the claim is that a significant portion of the economy was based on transparent relations of exploitation. Amin argues that this is true in so far as "the surplus levied by the ruling classes assumes the form of rents and various fees, often in kind or in labor: in short, the form of a tribute, whose deduction does not escape the immediate perception of those who shoulder its burden" [my emphasis] (Amin, 2009, p. 95). One objection that might be raised against this characterization of economic relations in ancient Egypt is that it does not take into account the redistributive nature of the Egyptian economy, i. e., the fact that the palace, and the temples as subsumed under the state during the Middle Kingdom (West, 2011, p. 521), did provide benefits for the peasants and craftsmen, at least when things went well. If this was the case, then the objection goes, why should we think that "objectively speaking" the peasants should have regarded these institutions as inherently exploitative? There is no denying the fact that laborers on state projects were remunerated for their efforts by state officials (Ezzamel, 2004, p. 498). However, the image of the ancient Near Eastern 
economies as "redistributive" economies, with the state responsible for provisioning peasants and craftsmen has been discredited by many contemporary scholars of the ancient Near East (Warburton, 2007, p. 184). In fact, it seems that the state in ancient Egypt did not provide as much material support for the peasants and craftsmen as one might be led to believe by the "redistribution model". For example, even though the state in ancient Egypt developed an elaborate system of food storage, there is no evidence that it "assumed major responsibility for public welfare in times of famine" (Trigger, 2003, p. 387). ${ }^{19}$ Hence, while there was an understanding of what constituted fair levels of taxation and acceptable demands for labour services, which might have contributed to the stability of the system, we should not exaggerate the extent of the benefits that the state provided to peasants and craftsmen. ${ }^{20}$ Nor should we lose sight of the central feature of this economic system, namely the transparency of exploitation (especially when compared to the opacity of exploitation in societies where the dominant mode of production is the capitalist mode of production).

Both Trigger and Amin de-emphasize commodity production and wage labor in their accounts of ancient tributary societies. This means that their views on ancient tributary societies are probably more applicable to ancient Egypt during the Old Kingdom (c.2690 BC- 2180 BC) and Middle Kingdom (c. 2055-1650 BC) than they are to ancient Mesopotamia. In Mesopotamia commodity production and waged labor (paid in silver money) were more significant aspects of the economy than in ancient Egypt during the Middle and Old Kingdoms (Smith, 2004; Warburton, 2005). In so far as this is true, one can say that ancient Egypt represents a "purer" instantiation of a society where the relations of exploitation were transparent. Nonetheless, we must recognize that the views of Trigger and Amin are somewhat dated insofar as they both underestimate the significance of monetization, wage labor, and commodity exchange in the ancient Egyptian economy during the Old and Middle Kingdoms. Brian Muhs argues that there is considerable evidence of waged work in ancient Egypt during the Old Kingdom, with wages being paid in beer, grain, or cloth (Muhs, 2016, pp. 37-39). He argues that during the Old Kingdom "weights of metal served as a measure of value, but they are almost never attested as a medium of exchange" (Muhs, 2016, p. 37). When we move to the Middle Kingdom, we encounter evidence that weights of gold were used as measures of value. Moreover, copper becomes a significant medium of exchange along with other media of exchange, such as cloth, grain, and beer, which were used to pay wages (Muhs, 2016, p. 75). There is also evidence of lending activities (Muhs, 2016, p. 77). But while Amin and Trigger underplay these more dynamic economic aspects, the crux of the matter is that there was a significant reliance on corvée labor in ancient Egypt during the Old and Middle Kingdoms. Hence, an important (and perhaps the most important) subset of relations of exploitation in ancient Egypt was comprised by transparent relations of exploitation.

It must be acknowledged that, as Mark Lehner notes, the evidence for "systematic corvée of native Egyptians remains indirect and vague" (Lehner, 2015, p. 471). However, while Lehner might be interpreted as arguing that the evidence for corvée labour is rather indirect, his more precise claim is that the evidence "for a regular national corvée" [my emphasis] is rather vague (Lehner, 2015, p. 474). The fact that one can doubt the existence of a national (out-of-district) corvée system is not important for my claim. For even those who doubt the existence of a regular national corvée do not deny that obligatory labour was a fact of daily life, i.e., services that needed to be rendered for various local lords and heads of powerful households (Lehner, 2015, p. 474). The transparency thesis is not dependent on the existence of a regular national corvée. It is sufficient that there be systematic demands for obligatory labour services at the local level. Moreover, despite the vagueness of the evidence, one can provide an abductive argument for inferring the existence of a systematic national corvée (i.e., a kind of inference to the best explanation). For example, Muhs argues that we can explain the evidence for censuses of people during the Middle Kingdom by invoking a demand for compulsory labor (Muhs, 2016, p. 64). Moreover, compulsory labor is more evident in Middle Kingdom documentation than in documentation from other periods (Muhs, 2016, p. 91). ${ }^{21}$ Hence, even if we acknowledge that the evidence for the existence of a national corvée (as opposed to local obligatory service) is indirect and vague, we should not discount an abductive justification for putting forward the hypothesis that it existed. Moreover, and this is the crucial point, the transparency thesis depends on the existence of obligatory labour requirements, regardless of whether they are imposed at the national level (i.e., taking people away from their home districts) or only at the local level. ${ }^{22}$ 


\section{2 | THE UTILITY OF THE CONCEPT OF INTERNAL CRITIQUE FOR THE STUDY OF MIDDLE KINGDOM LITERATURE}

It is important to note that I do not claim that the non-elites in ancient Egyptian society could not contest the claims made by the ruling elites using the conceptual tools which were developed by those very same elites. I have argued elsewhere that, when analyzing such cases, one should make a conceptual distinction between a tool which is not optimally suited for the actualization of one's objective interests and one which can never be used towards the actualization of one's objective interests under any circumstances, and that, from the standpoint of the exploited and the oppressed, the ideology of the ruling elite is rather like the former than the latter (EI Nabolsy, 2019a, p. 258). Moreover, as Barry J. Kemp reminds us, one should not overemphasize the broad acceptance of the ideals that originated from the court (Kemp, 2006, p. 317). I propose to slightly amend Kemp's claim. I argue that it was possible for members of oppressed social groups to utilize the ideals that emanated from the court in order to attempt to assert their interests. However, ultimately, I argue that in the context of Middle Kingdom Egypt, elite interests were predominant in shaping normative ideals and conceptual tools to such an extent that they severely limited their utility from the standpoint of members of non-elite social groups.

By turning to The Tale of the Eloquent Peasant, ${ }^{23}$ I analyze the manner in which the discourse that was produced by the ancient Egyptian elite regarding the concept of Maat could allow non-elites to contest the behavior and norms of the ruling class by way of a kind of internal critique. ${ }^{24}$ The concept of internal critique is another concept which is derived from Hegel. Internal critique is a critique of some claim which shows that the claim in question is illegitimate based on standards of normative or epistemic justification that are adhered to by the person who is advancing the claim. Thus, Hegel claims that: "the refutation must not come from outside, that is, it must not proceed from assumptions lying outside the system in question and that do not correspond to it" (Hegel, 1969, p. 580). Hegel points out that if we attempt to refute a system (or in our case, a claim) by adopting standards of justification which are not recognized by the proponents of the system (or claim) in question, then "the [proponents of the] system need only refuse to recognize those assumptions" in order to reject our refutation (Hegel, 1969, pp. 580-581). One can see how this model of critique and contestation might help us make sense of the possibilities which were open to a peasant who wished to assert his interests in the face of oppression in ancient Egypt. As John Baines and Norman Yoffee note, "the majority of people [in ancient Egypt and Mesopotamia] hardly had alternatives or points of comparison beyond their own social environment" (Baines \& Yoffee, 1998, p. 232). Hence, if contestation was possible it would have had to draw on conceptual resources which were available within the peasant's own society and the peasant's critique would have had to adhere to the epistemic and axiological norms which were adhered to by the elite. Egyptologists have pointed out that the institution of kingship itself was not questioned in ancient Egypt, i.e., there were revolts but no revolutions (Morris, 2013, p. 35). Thus it seems that revolts, when they occurred, did not question the normative framework within which the political structure was justified. Moreover, we should recognize that one of the central dualities in ancient Egyptian thought revolved around the dichotomy between that which is in and of Egypt and that which is beyond Egypt (Baines \& Yoffee, 1998). For the Egyptians, the land of Egypt was associated with Maat, which was perpetually threatened by chaos (Isfet), and Isfet was associated with everything foreign to Egypt (Cox, 2017, p. 373). Hence, a critique of Egyptian social structures that drew on conceptual resources which were associated with foreigners would have had little chance of succeeding. ${ }^{25}$

Moreover, the fact that in ancient Egypt, "elite high culture appears to stand in contrast to a poverty or an absence of a distinctive materialized ideology for others" (Baines \& Yoffee, 1998, p. 240), means that if we wish to look for sources for contestation, we need to look at critiques that took the form of internal critiques in the aforementioned sense. The concept of internal critique allows us to accept Baines and Yoffee's claim that elite high culture and value systems were essentially without competitors in ancient Egypt (and Mesopotamia), and that "if alternative value systems were present in these civilizations, they were so weak that they neither had a major effect nor are visible archaeologically" (Baines \& Yoffee, 1998, p. 240). Yet it also allows us to contest their claim 
that in those societies, "elites control symbolic resources in such a way as to make them meaningful only when it is they who exploit them" (Baines \& Yoffee, 1998, p. 234). I argue that we can recognize the dominance of the elites (and their value systems) without negating the agency of members of non-elite groups, as Baines and Yoffee seem to do.

It could perhaps be argued that the absence of evidence for the existence of an alternative cultural system that was produced by the exploited classes, does not directly imply that such an alternative cultural system did not exist. I think that this claim is correct. Hence, I do not wish to preclude the possibility that there was some kind of "little tradition" in the sense of "the distinctive patterns of belief and behaviour which are valued by the peasantry of an agrarian society" (Scott, 1977a, p. 8). According to James C. Scott such "little traditions" stand in opposition to the "great traditions" which are adhered to by the ruling elites in agrarian societies. Scott argues that within the context of this little tradition, there exists a "shadow society", which he defines as "a pattern of structural, stylistic, and normative opposition to the politico-religious tradition of ruling elites" (Scott, 1977a, p. 4). We cannot conclusively say that such a little tradition with its attendant "shadow society" did not exist during the Middle Kingdom. Scott himself recognizes that the differences between the "great tradition" and "little traditions" across societies vary tremendously. The distance between the great tradition and little traditions in an "indigenous civilization" is less than the distance between the great tradition and little traditions in a "borrowing civilization", i.e., a civilization where elite culture is based on an imported model (Scott, 1977a, p. 10). We may perhaps put forward the hypothesis that in ancient Egypt the distance between the great tradition and local little traditions was quite small, and that this explains the absence of a distinct materialized non-elite culture. ${ }^{26}$

Scott claims that "there is no such thing as a perfect ideological hegemony which socializes subordinate classes to accept either their fate or the values which ordain that fate" (Scott, 1977b, p. 242). However, there are certainly degrees of ideological hegemony, and it is not illegitimate to argue that ancient Egypt during the Middle Kingdom instantiated a society where ideological hegemony was tremendously well developed. This claim accords with our evidence which seems to suggest that even if there were little traditions, they were not efficacious to the degree that is to be found in Scott's case studies. Recent attempts that focus on the study of the poor in ancient Egypt have noted that even though it seems that by necessity the poor had to diverge from ideal elite norms in their practices, "the poor [nevertheless] subscribed to elite values" (Driaux, 2020, p. 13). In his case studies, Scott argues that "often the rebels made use of the egalitarian strains within the major religions of Islam, Buddhism, and Christianity to confront a social order in which all believers were decidedly not equal" (Scott, 1977a, p. 17). In this sense, Scott is pointing out that the peasants justified their rebellions by deploying an internal critique (in the aforementioned sense). However, it is not clear that there existed such salient egalitarian strains in ancient Egyptian religion and philosophical thinking. Hence, it is necessary to pay close attention to the specific cultural and historical context within which the peasants in ancient Egypt operated. ${ }^{27}$

I think that it is probably the case that ancient Egyptian religion and philosophy were not immune to internal critique (from the standpoint of the exploited), but that they were less amenable to internal critique from that standpoint than Buddhism, Christianity, and Islam. ${ }^{28}$ It should be clear that I do not mean to suggest that resistance was impossible. In fact, there is evidence for what Scott calls "everyday forms of resistance". There is evidence of Egyptian peasants hiding crops in order to prevent their surplus from being taken away in the form of taxation (Trigger, 2003, p. 376). This behaviour is one of the modes of resistance that Scott subsumes under the category of "everyday forms of resistance" (Scott, 1989, p. 39). I do not deny that such modes of resistance occurred in ancient Egypt; however, I am questioning their efficacy and their association with an influential "little tradition". In the case of ancient Egypt, I think we would be justified in posing the following question: "if all these acts of petty resistance add up to so much, where are the historical successes?" (Gutmann, 1993, p. 80).

I argue that the fact that the conceptual apparatus which was used to interpret social reality was primarily developed by the elite meant that there were objective limits constraining its use by non-elites. ${ }^{29}$ In general the state apparatus that was set up by the Twelfth Dynasty is regarded as being much more controlling and intrusive than the state that existed in earlier periods, e.g., there was a marked change in "bringing the provinces into line 
with the styles and practices of the capital" (Callender, 2000, p. 174). ${ }^{30}$ It seems that the elites in the capital were able to successfully project their control over cultural discourse. Hence, while Egyptian discourse regarding such concepts as justice (Maat) represented a contested terrain, it was nonetheless a terrain where the elites always occupied the high ground and thus were better placed to project their own interests. I do not argue that Egyptian intellectual discourse should be understood simply as propaganda, for the concept of propaganda presupposes an intentional attempt to mislead the recipients of the manipulated information. ${ }^{31} \mathrm{I}$ argue that there is no need to posit any kind of intention to mislead in order to explain the structure of some of the texts that I will examine below. We can recognize that in the literature of the Middle Kingdom, "there is no trace of intellectual rebellion or dissent" (Parkinson, 1997, p. 16) and that "Egyptians seldom allowed dissent to surface" (Baines, 2007, p. 180), without positing the existence of an intention by the authors of this literature to persuade people to acquiesce to their subservient status. ${ }^{32}$ In fact, it seems that at least some Egyptologists conflate the concept of propaganda with the concept of ideology when discussing the art and literature that was produced by the king's court. For example, Ronald J. Leprohon does not make a conceptual distinction between the concept of propaganda and the concept of ideology when discussing the role of visual arts and the texts associated with them in stabilizing ancient Egyptian society (Leprohon, 2015). ${ }^{33}$

The concept of ideology does not make any direct reference to intentions. ${ }^{34}$ One can define an ideological claim in the following terms: "a claim (or account) is to be regarded as ideological if and only if it is so evidently false that the only way in which we can explain why it is held is to appeal to its function in upholding the interests of the dominant group or class in the society in question" (EI Nabolsy, 2019b, p. 245). There are some limitations to this conception of ideology. First, this conception of ideology is primarily concerned with beliefs and judgments as opposed to unarticulated or tacit ways of being in the world. The concept of ideology as outlined above is derived from Richard W. Miller's account of Marx and Engels' understanding of ideology (Miller, 1984, p. 45). ${ }^{35}$ I have previously deployed this conception of ideology in the analysis of explicit philosophical discourse, hence the emphasis on explicit discursive claims as opposed to tacit unarticulated orientations towards the world. However, since this paper is primarily concerned with the analysis of the philosophical discourse which is to be found in some of the court literature of the Middle Kingdom, it seems appropriate to deploy a conception of ideology that focuses on explicit discursive claims. Moreover, there is an established distinction in some of the Marxist inspired literature on the sociology of knowledge between the concept of false consciousness and the concept of ideology. The concept of false consciousness is taken to apply to non-reflexive experiences or tacit orientations towards the world (which need not be articulated explicitly by the agents in question), whereas the concept of ideology is taken to apply to "a distorted conceptualization" (Eyerman, 1981, p. 54). Given that this distinction exists, I do not think that, in the context of this study, it is necessary to extend the purview of the concept of ideology such that it takes into account non-discursive orientations to the world. ${ }^{36}$

A second and perhaps more serious limitation to my conceptualization of ideology is that it is focused on false beliefs. Some scholars have argued that a set of claims does not have to be false in order for it to be ideological (Haslanger, 2017, pp. 150-151; Nielsen, 1980, p. 58; Rosen, 1996, p. 34). ${ }^{37}$ The motivation for this claim is that we can conceive of true beliefs that contribute to the stability of a social order, and that are held for social considerations as opposed to "rational" considerations. However, one response is to point out that while we can, by way of an example, conceive of empirical science in contemporary social formations as being promoted because it is in the interest of the ruling class (i.e., they have an economic interest in developing a better understanding of the causal laws that govern nature), it does not follow from this that empirical science as such is ideological (Leiter, 2015, $p$. 1185). ${ }^{38}$ Furthermore while I do not deny that many beliefs that are not evidently false can contribute to the stabilization of a given social formation, I do not think that all beliefs that can be assigned such a stabilizing function should be considered "ideological". Indeed one can argue that theorists who have inflated the extension of the concept of ideology in this manner have essentially conflated social consciousness tout court (and its causal entanglements with social structures, including its stabilizing function) with ideology (El Hassan, 1986). The restricted conception of ideology, which puts forward the claim that falsehood is a necessary but not a sufficient condition for 
a belief to be considered ideological also has a successful track record. To give just a few examples: it has been used to analyze race science (Gould, 1996, pp. 62-105), Malthusian political economy (Drucker, 1972), the history of post-Rawlsian Anglophone political philosophy (Mills, 2005), the history of Anglophone legal philosophy in the second half of the twentieth century (Leiter, 2015), and the claim, based on seemingly inexplicable misreadings of Ibn Khaldun, that has been advanced by several French historians of North Africa from the nineteenth century onwards, to the effect that the invasions of Arab tribes in the 11th century were what led to the crisis of medieval North Africa (Lacoste, 1984). Hence, I do not see why one should attempt to extend the scope of the concept of ideology in order to include true beliefs, given the success of the "traditional" conception of ideology as a theoretical framework for analysis.

Note that this formulation of the concept of ideology does not require any reference to any kind of intention on the part of those propagating the ideological claim in question (Mills, 1989, p. 424). ${ }^{39}$ Hence, while it may turn out to be the case that many of the claims that are advanced in the court literature of ancient Egypt are ideological in the aforementioned sense, there is no need to implicitly imply that the Egyptian court was involved in some kind of conspiracy to deceive people. ${ }^{40}$ Also, this formulation of the concept of ideology is focused on errors of commission, e.g., claiming that a human being (the king of Egypt) was the "son of Re's body", a description which is found in some of the inscriptions and literature from the Middle Kingdom (Lichtheim, 2006 [1975], p. 119; Parkinson, 1997, pp. 116, 208). However, errors of omission can also be ideological (Wood, 2004, p. 120). ${ }^{41}$ To this extent Fricker's concept of hermeneutical injustice with its focus on conceptual erasures and omissions is a helpful supplementary theoretical tool.

The transparency of relations of exploitation in ancient Egypt (along with other societies where the tributary mode of production was dominant), has led some Marxist theorists to maintain that the only way to explain how such societies could survive is if ideology was dominant (as in not just existent and influential, but essentially without significant challengers when it comes to interpreting social experience). ${ }^{42}$ As Samir Amin puts it: "The transparency of the relationships of exploitation in these societies demands that the ideological play a predominant role and be regarded as sacred" [my emphasis] (Amin, 2009, p. 111). If this is true, then the question arises how was ideology so dominant that it could not be challenged in any significant way? Perhaps the disparity between exploiters and exploited in the ability to shape collective hermeneutical resources was so great that any attempt to counter the dominance of ideology would not have been able to get off the ground so to speak. Here we have a clear case where the individuals who compose the ruling class "rule also as thinkers, as producers of ideas, and regulate the production and distribution of the ideas of their age: thus, their ideas are the ruling ideas of the epoch" (Marx \& Engels, 2013, pp. 64-65). Perhaps this situation obtained in ancient Egypt during the Middle Kingdom to a greater degree than in many other tributary societies.

While I focus on inequalities between socio-economic social groups or classes, it should be clear that the concept of "hermeneutical injustice" and the concept of ideology can also be applied in relation to other kinds of inequality. For example, one should note that the Egyptian state, with the king and the literate officials at its core (Baines, 1983), was a heavily male dominated state (Robins, 1993; Tyldesley, 1994). This male dominance can be seen in the language and concepts that people used in order to navigate their social reality. ${ }^{43}$ For according to the Egyptologist Renate Müller-Wollerman, there was no ancient Egyptian word for "rape" (Müller-Wollerman, 2015, p. 231). The Egyptians did not make a strict distinction between adultery and rape. This, however, does not mean that rape was not considered a crime in ancient Egypt, but it was a crime only when the woman who was raped was married: "the main issue was the offence of the personal right of the husband of the woman involved. The personal right of the woman herself was irrelevant and, therefore, whether the intercourse took place voluntarily or by force [was also irrelevant]" (Müller-Wollerman, 2015, p. 231). ${ }^{44}$ It follows from this that an unmarried woman who was subjected to what we would call "rape" would have had a difficult time in describing her experience (at least when compared to someone who has access to the word 'rape' in her language and where "rape" is a relatively salient concept in her culture) and in asserting her interests since there existed no word by means of which she could identify her experience. This would be an example of a semantically produced case of hermeneutical injustice 
(Medina, 2017, p. 45), i.e., a social experience (for surely "rape" existed as a phenomenon in ancient Egyptian society) with no adequate label for it. ${ }^{45}$

This difficulty which is created by the lack of adequate hermeneutical resources, because the available hermeneutical resources are skewed towards the interests of the dominant group in society (in this example men in a patriarchal society), is key in my view to understanding the relative stability of ancient Egyptian society during the Middle Kingdom, as well as the lack of sufficiently salient levels of dissent in the literature of the Middle Kingdom. This is not to say that there were no labels for avarice, partiality, and dishonesty that would have allowed peasants to criticize elites. To this extent there is an important difference in relation to the above example, which is a rather extreme case of semantically produced hermeneutical injustice. However, as I will argue below, the labels which could (and were) used to criticize elites were also situated in a conceptual framework that limited their utility for peasants. In short, I argue that while internal critique was possible, as can be seen in The Tale of the Eloquent Peasant, there were limits to its efficacy which were the effects of the manner in which intellectual discourse was structured in ancient Egypt during the Middle Kingdom.

\section{3 | CONTESTATIONS OVER EPISTEMIC AUTHORITY IN MIDDLE KINGDOM LITERATURE}

One especially significant feature which strikes the reader of the court literature of the Middle Kingdom is the manner in which epistemic authority is often monopolized by the king. The Tale of Sinuhe tells the story of Sinuhe an Egyptian official who fled Egypt when he heard that the old king was dead, Sinuhe flees to the West and lives among foreigners in Palestine, and yet despite his success there, he yearns to return to his homeland. Eventually the new king sends Sinuhe a letter which invites him to return home. The story concludes with Sinuhe's return to Egypt and his meeting with the new king. In The Tale of Sinuhe, which was composed in the first half of the Twelfth Dynasty (c. $1875 \mathrm{BC}$ ), the king who had had just ascended the throne following the death of his predecessor, is described in the following terms: "He is a lord of understanding, excellent of plans, effective of order" (Parkinson, 1997, p. 30). The claim that is being made here is a claim about the king's epistemic ability (his ability to know) and his central position at the apex of a hierarchy of epistemic agents. In fact, in Miriam Lichtheim's translation, this passage is translated directly as "He is lord of knowledge" (Lichtheim, 2006 [1975], p. 225). The king's dominant position in the hierarchy of knowledge is emphasized more than once in the narrative. Such as when the king is addressed as "the lord of perception, perceived of the people, perceives as the Majesty of the Court what your humble servant was afraid to say" (Parkinson, 1997, p. 38). The king is here depicted as able to know what Sinuhe cannot even articulate in words. John Baines has argued that in ancient Egyptian society there was a structural analogy between social hierarchies and hierarchies in knowledge (Baines, 1990). The king's location in both hierarchies, at least in official discourse, is identical. Not only does the king know things that others do not know, but what others know depends, in the final analysis, on what the king knows. Moreover, Sinuhe seems to blame his flight from Egypt, after hearing of the previous king's death, on the gods who put fear in his heart. The king interferes to overturn the injustice which was done to Sinuhe by the gods (who caused him to flee): "How can this be done for a servant whose heart led him astray to strange countries? So good is the kindness which saves me from death! Your spirit will let me make my end with my limbs at home!" (Parkinson, 1997, p. 37). Thus, the king's epistemic authority which is tied to the mediating role that he plays between humans and gods (L. D. Morenz, 2013, p. 138), extends not only to the human realm, but also to the realm of relations between deities and human beings (i.e., knowing when the gods have been unjust to someone and rectifying the injustice).

As Baines has noted "culture was defined in terms of kingship: no centrally sanctioned alternative existed" (Baines, 1995, p. 6). This point can be extended to knowledge, since knowledge is a central aspect of culture (Baines \& Yoffee, 1998, p. 237). The king was the embodiment of epistemic authority amongst humans, and he in turn derived his epistemic authority from the mediating role that he played vis-à-vis the gods. For example, in a building 
inscription belonging to Sesostris I, the king makes the following claim: "He who does all as he desires conveys to me what he wants known" (Lichtheim, 2006 [1975], p. 116). The position that the king occupies in the hierarchy of epistemic authority is also emphasized in The Teaching for King Merikare, where the king is described in the following terms: "The (Lord) of the Two Banks is a sage; the King, the lord of courtiers, cannot be foolish. When he came out of the womb he had understanding, and God [ntr ] has set him apart before a million other men" (Parkinson, 1997, p. 225). Moreover, the poor are depicted as incapable of disseminating objective judgments on social reality: "someone wealthy cannot be partial. Someone who does not suffer want is a lord of goods. A poor man cannot speak truthfully. He who says, 'If only I had' cannot be righteous, but is partial to the man who endears himself" (Parkinson, 1997, p. 219).Strictly speaking the claim here is not that the poor cannot know who is guilty and who is innocent, but that they cannot act in the appropriate way on their knowledge. Hence, their efficacy as epistemic agents (agents who can not only know things, but also do the appropriate things with their knowledge) is undermined. It should be noted that the function of this claim is not only to undermine the epistemic reliability (or more specifically, the testimonial reliability) of the poor, but also to justify the distribution of adequate amounts of surplus to the state's bureaucrats. However, the justification of the central role of the bureaucracy is bought at the expense of the belittling of the epistemic standing of those who occupy the lower rungs of the social hierarchy. It is true that there are texts where we encounter an emphasis on the wisdom of peasants and the lowly. However, as I argue below, such texts ultimately utilize the wisdom of the peasants in order to reassert the control of the state with its attendant hierarchies of epistemic authority.

We can see that the conditions for hermeneutical injustice are bound to obtain in a society where it is acknowledged that the parameters for what counts as knowledge are set by the king and his court: "Your Majesty is everyone's eyes" (Lichtheim, 2006 [1975], p. 117). On the stela of Sehetep-lb-Re, we encounter the following description of the king: "His eyes seek out everybody. He is Re who sees with his rays. Who lights the Two Lands more than the sun-disk, who makes verdant more than Great Hapy. He has filled the Two Lands with life force" (Lichtheim, 2006 [1975], p. 128). This connection to Re will be taken up again when we turn to the analysis of The Tale of the Eloquent Peasant below. In the meantime, it is important to note that the king is depicted as knowing everything, and as making knowledge itself possible, and we should connect this with the king's function of preserving social and cosmic order in general. For in his capacity as the preserver of social order, the king is not only the guarantor of justice (Manning, 2012), he is also the preserver of epistemic norms and epistemic hierarchy. ${ }^{46}$

The connection between social order and epistemic norms can be further understood through recognition of the polysemic nature of the Egyptian word 'Maat'. According to Siegfried Morenz: "Maat is right order in nature and society, as established by the act of creation and hence means according to context, what is right, what is correct, law, order, justice and truth" (S. Morenz, 1992, p. 113). Without the king, not only would there not be any recognizable social order, but the very norms which humans deploy in order to make knowledge claims would be undermined. Flight from the place where the king of Egypt reigns is depicted not only as a kind of social and physical self-harm, as when the king tells Sinuhe: "Act against yourself, act against yourself no more!" (Parkinson, 1997, p. 40), but also as a kind of self-destruction of one's capacity as a cognitive and epistemic agent. Moreover, chaos (social, cosmic, and epistemic) is never completely overcome in Middle Kingdom texts. ${ }^{47}$ The king is depicted as waging a constant struggle in order to keep the forces of chaos at bay (Shupak, 1992, p. 15). One can make sense of this claim by recognizing that it provided a legitimating device for the state, for if the state's exploitation of the peasantry is justified by the vital role that it fulfills in terms of upholding order against chaos, then we can recognize the importance of depicting chaos as a constant threat.

The Teaching for Merikare is set during the Heracleopolitan period (c.2081 - 1987 BC). It belongs to the genre of instructions for kings, and it depicts King Khety's advice to his son Merikare. Khety provides Merikare with advice as to how to retain power. In fact, The Teaching for Merikare has been compared to Machiavelli's II Principe insofar as both writings are concerned with question of how to attain and retain power (Langer, 2015). In The Teaching for Merikare, "the Asiatic", ${ }^{48}$ who is symbolically associated with chaos, is described in the following terms: "He cannot prevail; he cannot be prevailed over" (Parkinson, 1997, p. 223).Only the king and the state apparatus can hold chaos 
back. Hence, "to make revolt against you [the king] is to destroy heaven" (Parkinson, 1997, p. 225). Moreover, it seems that the Egyptians (or at least the Egyptian elite) could not imagine a world without the existing social hierarchies, without at the same time imagining the end of the world. Hence, in the "pessimistic literature" of the Twelfth Dynasty apocalyptic visions of the destruction of human society are associated with the collapse of social hierarchies and the inversion of social roles (R. David, 2002, p. 141). Note that I am here drawing on the concept of ideology and not on the concept of propaganda, for I am not arguing that the elites who controlled the production of court literature were intentionally invested in ensuring that other possibilities were obscured from view. Instead, I am arguing that when analyzing such claims, Egyptologists should draw on theorists of the sociology of knowledge such as Karl Mannheim who argued that material interests could lead to the creation of epistemic blind spots among the elites: "The concept 'ideology' reflects the one discovery which emerged from political conflict, namely, that ruling groups can in their thinking become so intensively interest-bound to a situation that they are simply no longer able to see certain facts which would undermine their sense of domination" (Mannheim, 1960, p. 63). It is in this sense that we should interpret the association of the inversion or destruction of existing social inequalities with apocalyptic events. For example, in The Words of Neferti (also called The Prophecies of Neferti), we get the following description: "I will show you the land in calamity, the weak man as the lord of force, and he who did the greeting greeted. I shall show you the lowermost uppermost, the man who followed after, now the man leading a generation. They will live in the necropolis. The wretched will make riches; the great will [beg] to exist. Only the poor will eat bread, while forced labourers are exultant. The land will have no Heliopolitan nome, the birthplace of every God" (Parkinson, 1997, p. 138). The collapse of the cosmic order is directly linked to a collapse of the bureaucracy, "Look there will be no officials in the affairs of the land, and what is done will be what is undone" (Parkinson, 1997, p. 135). For without the taxation surplus which is collected by the officialdom, the king will be unable to fulfill his role as mediator between human beings and gods, and consequently, "the Sun god separates himself from mankind" (Parkinson, 1997, p. 138).

In other texts which associate cataclysm with the inversion of social order, such as The Dialogue of Ipuur and the Lord of All (also called The Admonitions of Ipuur), elite interests are represented as general social interests. Along with the depiction of an inverted social world, "O, but beggars have become lords of wealth; someone who could not earn sandals for himself is a lord of riches" (Parkinson, 1997, p. 171), we get a description of a world where the collapse of the taxation system and the driving out of the officials who maintained the taxation system is depicted as being harmful to everyone: "Every town is saying, 'Let us drive away the strong from among us'..., but Elephantine and Thinis, the [districts] of upper Egypt, they produce no taxes [because of stri]fe" (Parkinson, 1997, pp. 172-173), and "O, but laughter is ruined, and [no longer] sounds. There is only groaning throughout the land, mixed with laments" (Parkinson, 1997, p. 174). However, we have to wonder to what extent this would have been true, given that the Egyptian state bureaucracy was not necessary for the maintenance of the irrigation systems which the Egyptian peasants depended upon, and which seem to have been organized at the local level (Allen, 1997). ${ }^{49}$ This is not to deny that the state was useful for ordinary people in terms of security, however we should not exaggerate its necessity for the primary producers in the production process itself. ${ }^{50}$

The text emphasizes the collapse of systems of control, and we even have an admission to the effect that what is truly catastrophic is not that the harvesting would stop (it is admitted that it would not stop), but rather the fact that the harvest is unrecorded: "[Look, he who recorded] the harvest now knows nothing of it; he who could not [plough for himself is a lord of fields]; the [harvesting] is happening, but cannot be reported; the scribe - his arms are [idle] in his house" (Parkinson, 1997, pp. 181-182). ${ }^{51}$ Here, the interests of the elite are represented as the common interests of all members of society, and this itself is a common feature of ideological discourse (Marx \& Engels, 2013). Therefore, we see that the concept of ideology, once it is carefully distinguished from the concept of propaganda is quite useful for Egyptology in general and for the study of the court literature of the Middle Kingdom in particular. Moreover, the concept of hermeneutical injustice (as a supplementary concept that emphasizes the significance of omissions in conceptual frameworks), allows us to recognize the limitations (from the standpoint of the articulation and assertion of the interests of the exploited) of the conceptual framework which was used to 
interpret social reality in ancient Egypt. If elite interests were identified with the common interests of all members of society, and if the only conceivable alternative to a system characterized by inequalities and elite domination was cosmic, social, and epistemic chaos, then we can see how difficult it would have been for a peasant to articulate a critique of his or her social environment as a totality.

However, there was still the possibility of internal critique and The Tale of the Eloquent Peasant shows how such a critique was possible, even though, it also shows its limitations in the context of the intellectual discourse of the Middle Kingdom. The Tale of the Eloquent Peasant has been dated to the mid-late Twelfth dynasty by R. B. Parkinson (1991). It has been described as essentially "a text on social justice" (Karenga, 2004, p. 70), and as a "classic of political philosophy" (Jeffers, 2013, p. 441). ${ }^{52}$ The story begins with a peasant named Khunanup who is heading to Heracleopolis, which was the capital during the Ninth and Tenth Dynasties (2160-2025 BC), in order to trade. On his way, he runs into Nemtinakht, a subordinate of the High Steward Rensi. The former takes his goods (and his donkeys) through a ploy, and the peasant proceeds to petition Rensi.The High Steward, upon hearing the first petition of the peasant, notifies the king of the eloquence of Khunanup. The king orders Rensi to withhold passing judgment on the case in order to encourage Khunanup to speak more about Maat (he also orders him to provide Khunanup and his family with food, without Khunanup being aware). Khunanup petitions Rensi a total of nine times (and the petitions are recorded in writing). Finally, the king tells Rensi that he can pass his judgment on the case, and Rensi gives all of Nemtinakht's property to Rensi (Jeffers, 2013, pp. 423-424). In the course of his petitions, Khunanup presents us with a description of the norms that were supposed to govern the behavior of officials: "speak not falsehood, for you are great! Be not light, for you are weighing! Speak not falsehood, you are the scales! Stray not, you are the standard! Look, you yourself are the very scales" (Parkinson, 1997, p. 66). Moreover, Khunanup uses the discourse of Maat in order to argue for his case: "when the secret of Maat is found, falsehood is thrown on its back to the ground" (Parkinson, 1997, p. 67). Parkinson elects to translate 'Maat' as 'Truth' throughout his translation of the text. However, I have decided to keep 'Maat' untranslated because in some contexts it clearly means 'justice' and not 'truth', e.g., when Khunanup pleads with Rensi to "do Maat, praised one whom the praised praise!" (Parkinson, 1997, p. 61).

Given the fact that Khunanup criticizes Rensi's inaction in very strident terms, even accusing of him of being "defect-maker of the whole land!" (Parkinson, 1997, p. 70), scholars have argued that this text can be interpreted as a complaint that is directed at "the entire corrupt bureaucracy of Egypt" (Shupak, 1992, p. 4). ${ }^{53}$ I interpret this text as an example of the internal critique that was possible within the confines of the intellectual discourse of Middle Kingdom Egypt. Parkinson has argued that it is possible to read the text in this way (although he does not explicitly draw on the concept of internal critique): "the tale can also be thought of as challenging the high culture in its own terms, by providing a dissident perspective on state ideology in the guise of a foolish peasant" (Parkinson, 2000, p. 43). Parkinson juxtaposes this manner of reading the tale with what he calls the "cynical Marxist reading", which claims that "the plot suggests an entrapment model of discourse - in which dissident voices are represented in order to contain them, and the dominant ideology ultimately appropriates their validity" (Parkinson, 2000, p. 42). I wish to suggest that the two interpretations are not in fact incompatible. For one can argue that while the tale presents a form of internal critique of Egyptian high culture, it also shows the limits of internal critique in the framework of Egyptian high culture given the absence of concepts that could be used to express the peasant's interests with sufficient clarity, as well as the objective weakness of the peasant vis-à-vis the state bureaucracy.

One remarkable aspect of the text is the manner in which the peasant is able to invert the hierarchy of mediating relations between humans and gods (Parkinson, 2000, p. 44). For whereas in the official discourse, it was the king who mediated relations between human beings and gods, the peasant at some point in the tale claims to be speaking in the voice of the Sungod: "You do not repay me for this perfect speech, which comes forth from the mouth of the Sungod himself! So speak Maat! Do Maat!" (Parkinson, 1997, p. 73). We have seen above that the king claimed to be the "son of Re's body" and that the king claimed knowledge of divine intentions. Thus, the peasant's claim is remarkable, for the peasant is essentially arguing that the hierarchy of mediating relations runs from the Sungod to him and then to Rensi in descending order (as opposed to the traditional hierarchy which runs from the 
Sungod to the king and then to Rensi). Furthermore, the peasant draws on the association of Maat with not only social justice but also cosmic order in order to argue that Rensi, insofar as he remains passive, is actually contributing to the destruction of cosmic order: "You act the same as everyone; your surroundings are awry, you who should be right! Defect-maker of the whole land! For a gardener of wretchedness is now watering his plot with bad..." (Parkinson, 1997, p. 70). Thus, the peasant connects Rensi's inaction with being a bringer of chaos to the "whole land". Moreover, we have seen how in The Teaching of King Merikare the poor man is depicted as someone who is incapable of upholding social norms and judging impartiality. In The Tale of the Eloquent Peasant, Khunanup draws on this trope in order to argue that "a lord of bread should be merciful, whereas might belongs to the deprived; theft suits one without belongings, when the belongings are snatched by the deprived; but the bad act without want - should it not be blamed? It is self-seeking" (Parkinson, 1997, p. 64). Khunanup is implying that if a poor individual steals in order to ensure his or her survival, then it is possible to provide justification for this act within the context of discourse around Maat, such as to render the act blameless.

We should also consider attempts at internal critique within the text that are not as successful because of the semantic inadequacy of some of the central concepts that are deployed in Middle Kingdom court literature. As Sherine El-Menshawy notes: "the king as good shepherd is an important Middle Kingdom theme" (El-Menshawy, 2014). ${ }^{54}$ For example, in a building inscription by Sesostris I, the king describes himself in the following terms: "He appointed me shepherd of this land, knowing him who would herd it for him" (Lichtheim, 2006 [1975], p. 116). The metaphor of the shepherd is used to both describe the role of the gods in relation to human beings and the role of the king in relation to his subjects. Humans are described as the "the flock of God" (Parkinson, 1997, p. 226). Thus, when Khunanup advances the following refrain in the course of his petitions to Rensi, "look, you are a shepherd is it not wrong for me that you cannot reckon?" (Parkinson, 1997, p. 67), we can understand him as drawing on a well-established metaphor in Middle Kingdom discourse. However, this metaphor is not conceptually suited for justifying a critique by a "member of the flock" which is directed towards the shepherd in the name of the responsibility of the shepherd to his flock (i.e., in a manner that would question the discourse which justifies the existing social hierarchy). For a shepherd is responsible for his flock (its well being and its protection), but he is not responsible to it (i.e., he cannot be questioned by it). Thus while the metaphor of the shepherd can be used to criticize officials, i.e., by drawing on the image of the shepherd who neglects his flock, or the shepherd who preys on his flock, this does not imply that the shepherd is responsible to his flock. For such criticisms are compatible with the assertion that the shepherd (the official) has failed in his responsibility to the king (and not to his flock). ${ }^{55}$ Hence, this kind of criticism does not by itself amount to a questioning of the discourse which justifies the existing social hierarchy. Rensi as a shepherd might in fact be responsible for Khunanup, but he is not responsible to him (he is only responsible to the king). ${ }^{56}$ In general, the metaphor of the shepherd, as it was used in ancient Egypt, did not imply that the official qua shepherd was some kind of public servant. As Christopher Eyre puts it: "the official presents himself as a responsible shepherd, within a hierarchy, but there is no indication that he conceived of himself as a public servant" (Eyre, 2011, p. 704). I.e., the official is responsible to his superiors but not to his flock. In this sense, we can say that one of the central themes of ancient Egyptian discourse on political authority was more suitable to interpreting social reality from the standpoint of the interests of the elite than from the standpoint of the interests of the exploited. ${ }^{57}$ Moreover, given that there was no conception of "economics" or the "economic", it follows that there was no conception of "economic exploitation". The concept of "injustice" which the Egyptians undoubtedly possessed is less specific than the concept of "economic exploitation".

This is not to deny that complaints about high taxation, and unreasonable demands for labour services were economic in content. However, the point is that such economic demands could not be articulated in a manner that could question the normative status of the social order as a whole. A peasant could not articulate the view that the social totality, of which he was a part, was, at its root, based on the economic exploitation of the primary agricultural producers. It is true that this situation was not unique to ancient Egypt, indeed it may be found in most premodern agrarian hierarchical societies. However, the extent of the inadequacy of the hegemonic hermeneutical framework combined with the dominance of "elite culture" may have set Egyptian society apart from other agrarian 
tributary societies. To this extent it can be invoked in order to explain the relative stability of ancient Egyptian society in combination with other factors such as geography. After all, the primary aim of this paper is to show that the "ideological factor" should not be neglected in the analysis of the causal factors which contributed to the stability of ancient Egypt.

The lack of a functionally equivalent concept to the concept of "economic exploitation" combined with the association of inversions of social hierarchies with chaos meant that even in The Tale of the Eloquent Peasant, "it is not the opposition of rich and poor that caused annoyance: there was no possibility to conceive society other than a vertical one" (Gnirs, 2000, p. 142). These examples illustrate the dilemma faced by the peasantry in Egypt. On the one hand, "the voice of the common man with no position in the administrative hierarchy is practically inaudible in ancient Egyptian culture" (A. David, 2011, p. 80). On the other hand, any resistance would have required the adoption of a conceptual framework that is not optimally suited to the expression of the "common man's interests". This demonstrates the utility of drawing on the concept of hermeneutical injustice for understanding ancient Egyptian intellectual discourse. We can recognize that there was room for internal critique, but that given the structure of ancient Egyptian intellectual discourse, once one started to articulate a critique in concepts drawn from this discourse (and given the dominance of high culture one essentially had no other choice) one was restricted by the lack of adequate concepts for interpreting social reality from the standpoint of the interests of the exploited.

In relation to contestations over epistemic authority, we have noted above that Khunanup asserts his position as a subject capable of knowledge, and as a subject capable of teaching Rensi the duty of officials. However, we should also recognize that there is a developing dialectic in the story, and it terminates with the peasant recognizing that he is the one who is being taught and being used to teach (and not as a teacher but as an object of demonstration). Matthew A. Light has argued that in fact Rensi's silence is meant to teach the peasant something about the importance of the law and of legal procedure: "by emphasizing that the peasant must experience the bitterness of submitting to Rensi's protracted interrogation in order for justice to be done, The Eloquent Peasant thus reinforces its educative program of explaining and justifying the functioning of the legal process" (Light, 2000, p. 112). It is important to note that in the final section of the narrative, the respective positions of the peasant and Rensi are inverted, i.e., it is the peasant who becomes the hearer. Rensi assumes a commanding tone: "And the High Steward Meru's son Rensi said, 'Now wait here and hear your petitions!' And he caused every petition to be read out from a fresh roll according to [its] content" (Parkinson, 1997, p. 75). The peasant's petitions have been recorded and Rensi reveals that he has been listening carefully to the peasant's petitions, but note that strictly speaking the peasant's eloquence was not by itself sufficient to bring him justice (if we assume that being given all of Nemtinakht's possessions is sufficient to compensate him for the humiliations that he has suffered). Even though one should recognize that words can bring about transformations in the world (Hare, 2000), ultimately, the peasant is dependent on others for vindication (Bontty, 2000), as it is the king who finally authorizes Rensi to judge the case: "And the High Steward Meru's son Rensi had them presented before the Majesty of the Dual King Nebkaure, the justified. And they seemed more perfect to his heart than anything in this entire land. And his Majesty said, 'Judge yourself, Meru's son!'” (Parkinson, 1997, p. 75). In the final analysis, it is the king who gives permission for Rensi to judge the case.

In fact, it is possible to read the tale as objectifying the peasant, in the sense that the peasant is treated as an object of demonstration, and insofar as the peasant is treated as a means for identifying faults in the administrative system. The peasant in his discourse on Maat is in fact reinforcing the common identity which was constructed by the members of the upper echelons of the Middle Kingdom bureaucracy. In fact, his speeches which ostensibly aim to exalt Maat seem to be emphasizing the centrality of the bureaucracy: "Speak not falsehood, for you are great! Be not light, for you are weighty! Speak not falsehood, you are the scales! Stray not, you are the standard! Look, you yourself are the very scales: if they tilt, then you can tilt. Drift not, but steer! Rescue with the tiller rope! Seize not but act against the seizer! A selfish great one is not truly great. But your tongue is the plummet; your heart is the weight; your 
lips are its arms. So if you disregard the fierce, who will beat off wretchedness?" (Parkinson, 1997, p. 66). This passage reinforces the centrality of the bureaucracy for the functioning of the state and society. Note that the criticism of the bureaucracy which is in the text is not incompatible with the affirmation of the importance of the bureaucracy. For in the text the bureaucracy is criticized precisely because when it malfunctions the entire social order is adversely affected. We can compare this message with the message of The Teaching of Khety (also known as The Satire of the Trades), where the importance of the bureaucracy for upholding the social order is emphasized: "He [the scribe] fills another's want even before that person can leave the court content ... Now it is greater than any other profession. There is not its like in the land" (Parkinson, 1997, p. 275). In this text there is also explicit awareness of the fact that the scribes live off the labor of the agricultural producers: "Set your heart to writings! Observe how it rescues from labor!" (Parkinson, 1997, p. 275).

When we consider that it seems likely that the text of The Tale of the Eloquent Peasant was composed by a well-educated high ranking official and that its intended audience could have been the king and other high ranking officials (El-Menshawy, 2014, p. 425), then we can recognize that one of its primary functions was to make clear to the king and other high ranking officials the importance of having a well-trained and well-paid bureaucracy. Moreover, there is an emphasis on the importance of listening to the peasant, as a way to respond to inefficiencies in the administrative system. Listening in this context accomplishes two things from the perspective of the bureaucrat. First, it prevents discontent from transforming into outright revolt. The literature of the Middle Kingdom emphasizes the cathartic function of listening to petitions and complaints. For example, in The Teaching of the Vizier Ptahhotep we are explicitly told that "If you are a leader, be calm while you hear a petitioner's speech! Do not prevent him from purging his body of what he planned to tell you! A wronged man loves to pour his heart out more than achieving what he came for. About someone who prevents petitions, they say, 'So why does he thwart it?' Everything for which a man petitioned may not come about, but a good hearing is what soothes the heart" (Parkinson, 1997, pp. 255-256). Hence, we see that the bureaucracy explicitly recognized the cathartic function of listening to petitions, even if the petitioning process does not lead to restitution (let alone any kind of structural transformation). The second thing that is accomplished by listening, from the perspective of the bureaucracy, is that it allows for the detection of corruption. Corruption is problematic from the standpoint of the state insofar as it hinders its efforts to collect taxation (i.e., if the peasantry is subject to pressures to bribe local officials, they may not be able to pay the amount of taxes that state expects from them). Gnirs argues that we should understand the text to be a result of the reformist movement that emerged during the Middle Kingdom, whose aim was to reform the bureaucracy in order to push back against the corruption which arose as a result of patronage networks (Gnirs, 2000, p. 154). ${ }^{58}$ Thus, the peasant was used as a means for detecting inefficiencies in the bureaucracy.

\section{4 | CONCLUSION}

In the final analysis, we can say that while it is true that there was room for maneuver and for internal critique, the efficacy of internal critique was hindered by the structure of the intellectual discourse of Middle Kingdom Egypt. This intellectual discourse was suitable for the interpretation of social reality in a way that allowed the elites to assert their interests, but it was not suitable for the interpretation of social reality in a way that accorded with the interests of the exploited peasantry. Ultimately we can partially explain the stability of ancient Egyptian society by recognizing that the disparity (between exploiters and exploited) in the ability to shape collective hermeneutical resources was so great that any attempt to counter the hegemony of the dominant ideology would not have been able to get off the ground so to speak. In other words, we get a vicious cycle. This cycle is only vicious from the point of view of the interests of the exploited. From the point of view of the exploiting elite a vicious cycle like this one is a dream come true. 


\section{AUTHOR CONTRIBUTION}

I am the sole author of this manuscript.

\section{ENDNOTES}

${ }^{1}$ I read Miranda Fricker as essentially advancing an account that is compatible with at least some versions of the Marxist concept of ideology, even though she distances herself from Marxist concepts of ideology in her development of the concept of hermeneutical injustice in the context of analytic feminist social epistemology. There is convergence between some of the key concepts of contemporary social epistemology (e.g., the concepts of epistemic and hermeneutical injustice) as a sub-field of analytic philosophy in the Anglophone world, and some of the concepts that were developed much earlier by Marxist philosophers and social theorists (Babbitt, 2017), even if the former have not acknowledged the latter (this neglect calls for sociological explanation, but such an explanation is beyond the scope of this paper). Charles W. Mills has recently argued that the concept of "hermeneutical injustice" (which has become quite popular in the subfield of social epistemology) can be fruitfully combined with a variant of the Marxist concept of ideology in social analysis (Mills, 2017, pp. 104-105). I have also recently attempted to show that the concept of hermeneutical injustice and a variant of the Marxist concept of ideology can supplement one another (El Nabolsy, 2019a). In this paper, I am not at all interested in showing that the concept of hermeneutical injustice should supplant (rather than merely supplement) the concept of ideology or other concepts such as the concept of false consciousness (Szacki, 1966), or Bourdieu's concept of misrecognition, or the concept of hegemony (Burawoy, 2012). Instead, the aim is to show that that we can deploy the concept of "hermeneutical injustice" (or a functionally equivalent concept) in order to contribute to the explanation of the relative stability of ancient Egyptian society during the Middle Kingdom period.

2 By 'collective understanding', Fricker means to note that that the phenomena which are obscured from understanding by the lack of adequate conceptual resources for detecting and interpreting them are obscured from the understanding of both oppressed and oppressor (even if this conceptual deficit is more harmful for the former). We should also note that Fricker employs the term 'hermeneutical resources' to refer to the conceptual resources that are available for the interpretation of social reality in a given society. Note that 'hermeneutical' does not carry methodological connotations (i.e., a hermeneutic method), instead it refers to the function of those conceptual resources (i.e., the interpretation of social realities).

${ }^{3}$ This is obviously not a novel claim, as Mills points out, 'long before mainstream epistemology 'discovered' that 'testimony' and social circumstances were relevant to actual human cognition, Marxism was rejecting any kind of individualist Cartesian [epistemological] problematic" (Mills, 2017, p. 101).

${ }^{4}$ For an overview of the debates on the origins of nomes, see (Willems, 2014, pp. 5-23).

${ }^{5}$ Although the conventional framing of the "democratization of the afterlife" hypothesis has been recently criticized (Willems, 2014). Willems argues that, in its standard form, the democratic hypothesis is false in so far as it claims that texts which had been previously reserved exclusively for the king's burial were made available to everyone. Instead Willems argues that those texts (commonly referred to as "coffin texts") became available to the nomarchs and not to the wider Egyptian population (Willems, 2014, p. 163). The coffin texts, on this view, were cultural expressions associated with the nomarchs, and they disappeared with the disappearance of the nomarchs.

${ }^{6}$ The system of nomarchs was eventually abolished, and mayors reported directly to the central government without the mediation of nomarchs (Morris, 2018, pp. 158-159).

${ }^{7}$ Explicit political treatises and literary works in general seem to first emerge in ancient Egypt during the First Intermediate Period and the Middle Kingdom (Trigger, 2003, p. 591). Thus strictly speaking, the first written explicit philosophical discourse in ancient Egypt emerges during this period.

${ }^{8}$ Some scholars continue to reject the thesis that there could be anything like Egyptian philosophy, instead when faced with the existence of Egyptian texts that argue about fundamental questions related to the justice of the Gods, the duties of officials, and the justification of the state's existence, they argue that what we have here is only a "protophilosophy" (Dunca, 2012, p. 28). I recognize the existence of ancient Egyptian philosophy, but I disagree with scholars, such as Théophile Obenga (Obenga, 2004), who think that we can understand it by abstracting from its socio-historical context, i.e., the context of a tributary social formation. For example, Obenga, because he ignores the social context of Egyptian philosophy, claims that "there was no human servitude or slavery" in ancient Egyptian society (Obenga, 2004, p. 46). This is clearly false, for we have evidence that indicates that it was not uncommon for people to have to sell themselves into slavery (Silver, 2009). There is also direct evidence that captured foreigners were used as captive labour for the construction of royal pyramids (Lehner, 2015, pp. 477, 480-481). There is also evidence of "labour camps" in lower Nubia during the Middle Kingdom (Morris, 2018, p. 78). Thus we can say that while slaves were not numerous in ancient Egypt (especially when compared to the slave societies of ancient Greece and Rome), it is quite clear that foreign captives were enslaved (Trigger, 2003, p. 160). 
9 This endeavour is further complicated by the fact that it is difficult to speak of an originary Urtext in a manuscript culture such as that of ancient Egypt (Parkinson, 2002, p. 52).

10 It seems that in Egypt political conflicts were often expressed in religious language. For example, "objections to the abuse of royal power in ancient Egypt often took the oblique form of requests that the king observe his filial duty to attend to the welfare of the cults of the provincial deities" (Trigger, 1993, p. 88). Trigger generalizes this claim to apply to most early civilizations(Trigger, 2003, p. 409). This claim was also held by earlier Marxist theorists (there are clear Marxist influences on Trigger, but he does not present himself as a Marxist). Engels, in his The Peasant War in Germany, argued that pre-modern class struggles were often carried out in the context of religious discourse, e.g., peasant heresies that called for "the restoration of early Christian equality" (Engels, 1966, p. 15). However, for Engels, the expression of class antagonism in terms of religious discourse was supposed to come to an end with the French Revolution (Löwy, 1998, p. 84). Moreover, while it is true that Engels' analysis emphasizes the agency of peasants and their ability to draw on elements of Christian conceptual frameworks in order to assert their interests (Wolf, 1987, p. 85), we must recognize that this is dependent on the nature of the dominant conceptual frameworks (i.e., in some societies the dominant conceptual frameworks may not be very amenable to re-appropriation and re-configuration from the standpoint of the exploited social groups).

11 As Christian Langer puts it: "The Egyptian elite did not simply act; they were aware that they acted in this way, and they knew why: to maintain the social order determined by Maat and thus retain power" (Langer, 2015, p. 67).

12 Moreover, John Baines has noted that there is no evidence for the existence of scribes who did not work for the state's bureaucracy (Baines, 1983).

13 This issue points to the problem of the transmission of ideas from the ruling class to the dominated classes. Some scholars have argued that given the limitations on means of communication in pre-capitalist social formations, the transmission of ideas from the ruling class to the dominated classes was not effective (Abercrombie \& Turner, 1978). However, with respect to the court literature of the Middle Kingdom recitation was a possible means of transmission to a non-literate audience (Parkinson, 2002, p. 80).

14 Physical punishments were inflicted upon those who stole royal property (Lorton, 1977, p. 44).

15 The Egyptian historian Mahmoud Ismail has written of a "revolution" [thawra] during the First Intermediate Period (Ismail, 2009, pp. 21-26). However, while one can respect Ismail's attempt to write the history of Egypt in a way that centers the rebellions of the marginalized against their oppression, in opposition to Witffogel's emphasis on total submission (Wittfogel, 1963, p. 149), one must also point out that Ismail's claim is without evidential support. There is evidence of resistance to exploitation, but resistance does not amount to "revolution".

${ }^{16}$ For a convincing defence of the thesis that, in general, the dominant mode of production in pre-capitalist class societies was the tributary mode of production, see (Haldon, 1993, pp. 70-139).

17 It is interesting to note that Antonio Loprieno argues that in some important respects, there are structural similarities between Middle Kingdom Egypt and late Medieval Europe (Loprieno, 2000, p. 191). This is interesting precisely because the social structures of late Medieval Europe are described by Amin as instantiating an underdeveloped or peripheral form of the tributary mode of production with relatively centralized states like ancient Egypt instantiating a more developed form of the tributary mode of production (Amin, 2009, pp. 233-238).

18 According to an alternative explanation, the subject matter of economics only emerges as a separate differentiated sphere when the economy becomes disembedded from society, and this development, which involves the rise of a market economy, did not take place in ancient Egypt or ancient Mesopotamia. As Karl Polanyi notes: "the prime reason for the absence of any concept of the economy [in the ancient world] is the difficulty of identifying the economic process under conditions where it is embedded in noneconomic institutions" (Polanyi, 1957, p. 71).

19 As Ellen Morris notes, "if the distribution of food to the hungry was indeed an important component of the king's mandate to rule, however, it is remarkable how little this message seems to have been promoted by the court" (Morris, 2013, p. 60).

20 Some evidence suggests that what was considered a "fair" level of taxation varied according to conditions. Hence, in years of famine the state was expected to reduce taxes on crops (Trigger, 2003, p. 387).

21 However, the evidence is not completely unequivocal. For example, the "Duties of the Vizier" states, according to Muhs' interpretation, that it is duty of the vizier to register people for compulsory labour and to punish those who flee from their labour service. However, the text itself is not unequivocal: "(13) Now, as for any action of the vizier in hearing cases in his office, as for anyone [in]efficient in any [mission?] whom he will hear concerning it, or anyone whose (labour) duty he will not remove (14) when his hearing comes to it, then it is to be added to the roll of transgressors that is in the great prison, and likewise for any official of his in... whose duty he will not remove. If their case arises again, the entry on the roll of transgressors should be reported (15) with a summary of the case for which they were added on the roll concerning their failing" (quoted from Muhs, 2016, pp. 64-65). We can see that while Muhs' interpretation is not unreasonable, the text itself is not unambiguous. Moreover there are debates on the terms used in connection to corvée labor during the Middle Kingdom, see (Quirke, 1988). 
22 Note that the transparency of relations of exploitation does not entail intensity of exploitation. E.g., Trigger argues that "exploitation was not as severe in the early civilizations as it was in many more developed preindustrial ones" (Trigger, 1993, p. 53), that may be true, but for the point made here what is important is the transparency of relations of exploitation. This is the point of Marx's comparison between the condition of the proletarian and the condition of the serf: "the corvée can be measured by time just as well as the labor which produces commodities, but every serf knows that what he expends in the service of his lord is a specific quantity of his own personal labor-power. The tithe owed to the priest is more clearly apparent than his own blessing" (Marx, 1976, p. 170). However, it is clear that a society where relations of exploitation are transparent in this manner requires that they should be interpreted in a religious manner (or in some other manner that obscures the exploitative nature of such relations).

${ }^{23}$ The Tale of the Eloquent Peasant is regarded as the key Middle Kingdom text on Maat (Karenga, 2004, p. 168).

${ }^{24}$ Maat can be glossed as "the moral and physical order of the universe" (Lloyd, 2013, p. 365). It can also, depending on context, be rendered as "truth" or "justice".

25 Although we should not exaggerate this point, since some Egyptologists have argued that some deities were of foreign origin, e.g., Bes (Fakhry, 2003, p. 83).

26 In such cases, it would be false to think that "for almost every institutional element of the great tradition there is a counterpart in the little tradition, a 'shadow' institution, that stands in opposition" (Scott, 1977c, p. 274). Even Parkinson who argues that some tales such as Cheops' Court may indicate the existence of a "lower tradition", argues that "nothing, however, suggests radically different social contexts for literary compositions [that can be identified as evidence of a lower tradition], or suggests that Cheops' Court represents a rejection of official language in favour of unofficial language in the evolution of a new self-consciously 'proletarian' form of literature" (Parkinson, 2002, p. 143). In other words Cheops' Court is "lower" only in the sense that it deals with mundane or "low" aspects of life.

27 Some scholars have criticized Scott's generalizations for ignoring the specific cultural and historical contexts of the peasants in the different societies that he compares (Hunt, 1988, p. 165). Moreover, even if we endorse Scott's emphasis on "little traditions", we should not forget that symbolic rebellions are compatible with an acceptance of the established order as normatively justified (Gutmann, 1993, p. 75).

${ }^{28}$ Perhaps there is something distinctive about such religions that makes them more amenable to internal critique. I am rather wary of recent attempts to revive the concept of an "Axial Age" and I cannot engage with those attempts in any detail here (Bellah, 2005; Boy \& Torpey, 2013). However, I do think that Arnaldo Momigliano points to something significant when he emphasizes that during this age (600-300 BC, for Momigliano), "new models of reality, either mystically or prophetically or rationally apprehended, are propounded as a criticism of, and alternative to, the prevailing models. We are in the age of criticism..." (Momigliano, 1975, pp. 8-9). Moreover, it seems that the dominant ideology in classical antiquity, for example, was amenable to internal critique in a manner that allowed for the justification of slave revolts (Urbainczyk, 2008, p. 79).

29 I think that there is a significant difference (that amounts to almost a qualitative difference) between internal critique in relation to a pre-modernist philosophical framework and internal critique as carried out within the philosophical framework of modernity (i.e., the discourse of individual human rights, and a secularized, de-mystified view of human history). From the standpoint of the interests of the oppressed and the marginalized, it seems that internal critique is more efficacious (and brings about more progress), when it is carried out within the philosophical framework of the discourse of modernity. In other words, it is only in the modern period that internal critique becomes as efficacious as Hegel took it to be, at least in relation to social and political struggles. Obviously, I cannot argue for this claim in this paper. However, I think that this point is important in relation to understanding the limits of internal critique in a society like that of ancient Egypt during the Middle Kingdom.

30 This is most evident in artwork where we see a convergence with the style of the capital (Callender, 2000, p. 174).

${ }^{31}$ For example, the Egyptologist Georges Posener has argued that the literature of the Middle Kingdom period constitutes a form of propaganda (Parkinson, 1997, p. 14). Posener was led to this view by the fact that much of the literature, especially the "Teachings", was written by the elite for an elite audience, with the dominant themes being "state themes" (Parkinson, 1997, p. 14).

32 The over-emphasis on propaganda as a stabilizing force is a prominent feature of Karl Wittfogel's account of "hydraulic societies" (Witffogel, 1963, p. 135), and its continued deployment is one of the more undesirable elements of Wittfogel's influence. For it presumes that scholars can ascribe certain intentions to historical agents even when there is no evidence to support such ascriptions.

33 I agree with Parkinson that Middle Kingdom literature cannot be reduced to propaganda (Parkinson, 2002, p. 279). However, in Parkinson's book the distinction between the concept of propaganda and the concept of ideology is not clarified.

${ }^{34}$ Carolyn A. Thériault recognizes that intention to manipulate is a necessary condition for a text to be considered propaganda. Thériault argues that The Instruction of Amenemhet should not be considered as propaganda (Thériaul, 1993). I agree with this claim, and I think that we can apply the concept of ideology in order to better understand the function of that text. 
35 A similar conception of ideology as the product of truth distorting social forces is also to be found in Althusser's writings, e.g., (Althusser, 1971 [1969], p. 73).

36 Although this does not of course imply that the study of such orientations in ancient Egypt is unimportant (although it is very challenging from a methodological standpoint).

37 Rosen is in fact critical of the theory of ideology as such, although his critique proceeds by essentially ignoring more sophisticated formulations of the theory of ideology, e.g., the version developed by Charles W. Mills (Mills, 1986, 1989, 1994).

38 Indeed we can imagine that true scientific beliefs can also contribute to legitimizing the ruling class, insofar as they allow the ruling class to demonstrate its ability to guide society towards some kind of "mastery over nature". However, in my view, this is not sufficient to think of them as ideological. My view is derived from the standpoint of classical Marxist philosophies of science. A key feature of classical Marxist philosophies of science was that they held that all knowledge, including scientific knowledge, was conditioned by socio-economic conditions, without believing that this fact by itself was sufficient to cast doubt on the rationality of science or the truth of specific theories (Sheehan, 2017 [1985], p. 5).

39 In one of the classical formulations by Engels, it is claimed that the fact that the propagator of an ideological claim is not aware that it is an ideological claim is a necessary condition for it to be considered an ideological claim: "Ideology is a process which is, it is true, carried out consciously by what we call a thinker, but with a consciousness that is spurious. The actual motives by which he is impelled remain hidden from him, for otherwise it would not be an ideological process. Hence the motives he supposes himself to have are either spurious or illusory. . . He works solely with conceptual material which he automatically assumes to have been engendered by thought without inquiring whether it might not have some more remote origin unconnected therewith." (Engels, 2004, p. 164).

40 Moreover, it does not follow from this fact that some of this literature is not philosophical. A set of texts can be both philosophical and ideological.

${ }^{41}$ Not all ideological accounts are ideological because they commit errors of commission; some are ideological precisely because of the kinds of omissions that they make. E.g., the accounts that are taught to schoolchildren in the United States of America of the life of Christopher Columbus are ideological precisely because of their omission of, among other things, Columbus' institution of genocidal practices against the Taino people (Koning, 1976).

42 Strictly speaking we should emphasize the concept of "tributary social formations" as opposed to the concept of a tributary mode of production, because the former concept allows us to recognize that while the tributary mode of production was dominant in such societies, there were also other modes of production which were articulated with that mode of production (Amin, 1990).

43 Scholars who are interested in the contemporary relevance of Egyptian thought have emphasized that the position of women in ancient Egypt was in general much better than the position of women in west Asian societies (the Levant, Mesopotamia, and Anatolia) and classical Greece and Rome (Karenga, 2004, p. 79). This is certainly true insofar as women were recognized as full legal entities in ancient Egypt (Trigger, 2003, p. 185). However, scholars such Karenga ignore key structural limitations on the participation of women in the formulation of the dominant cultural discourses in ancient Egypt, e.g., the fact that there were no women scribes. Karenga conflates the claim that Egyptian society was characterized by less male dominance than ancient Greek society (for example), with the claim that women and men were equal in ancient Egyptian society. The former claim is true, the latter is not (e.g., men dominated political office in ancient Egypt).

44 We should not neglect the fact that men in class-based pre-capitalist societies have an interest in protecting "their women". Thus we find prohibitions against rape in the Codex Hammurabi, the Middle Assyrian Law, and in the Hittite Laws. In general, in those law codes the injured party in rape crimes is the father or husband of the raped woman, and not the woman herself (Lerner, 1987, p. 116).

45 This example parallels Fricker's key example of how women experienced "sexual harassment" before there was a label for it that allowed them to adequately interpret and communicate their experiences (Fricker, 2007, pp. 150-152).

46 While some of these elements existed in Mesopotamia, we should nevertheless recognize that the position of the king in Mesopotamian city-states was not as strong as the position of the king in the Egyptian territorial state. In Mesopotamia kings were perceived as human, whereas in Egypt, the kings were ascribed more divine properties (Trigger, 2003, p. 85). Furthermore, power was more widely diffused in Mesopotamian city-states than in territorial states such as Egypt (Trigger, 2003, p. 103). In Mesopotamia, the local elites were less integrated with the central courts, and unity above the city-state level was short-lived and shallow (Hill et al., 2013, p. 20), e.g., the attempts at centralization which were launched from Akkad and then from Ur during the last centuries of the third millennium (Van de Mieroop, 2016). This competition between provincial elites and the central courts in Mesopotamia placed limits on the cultural authority of the kings in Mesopotamian city-state. Thus, the kings in Mesopotamia did not possess the status that was possessed by the Egyptian kings. In the relatively more decentralized city-states of Mesopotamia, we also have more evidence of popular unrest in response to economic exploitation (Trigger, 2003, p. 203). The city assemblies also played a greater role in Mesopotamian city states, which set limits to the status and power of the king (Garfinkle, 2013, p. 110). The 
suggestion here is not that the different discourses about kingship that existed in Egypt and Mesopotamia are sufficient to explain the relative stability of the Egyptian state compared to the more ephemeral Mesopotamian attempts at creating territorial states (Moreno Garcia, 2013, p. 185), for we must not neglect geographical factors and other "material" factors. Instead, the suggestion is that different degrees of cultural dominance associated with different political structures may play an explanatory role.

47 This constant struggle between the forces of chaos and the forces of Maat is a general structural feature of ancient Egyptian cosmological texts (R. David, 2002).

48 The figure of the "Asiatic" refers to the foreigners from the Levant who threatened Egypt's eastern borders.

49 The ancient Egyptian bureaucracy, when analyzed through the surviving administrative texts, "seems to have been concerned mainly with facilitating the transfer of produce to the various centers which made up the 'court' and to its provincial outliers, and with supervising constructional work, rather than with the maintenance of the agricultural system" (Trigger, Kemp, O'Connor, \& Lloyd, 1983, p. 176). It is now widely agreed that irrigation in Egypt was not coordinated by the state (Manning, 2013, p. 64). The thesis that the Egyptian state was responsible for the construction and maintenance of irrigation systems, a thesis associated with Karl Wittfogel (1963, pp. 26-29) but advanced much earlier by Adam Smith (Helmy, 2015, p. 261), has been discredited. Wittfogel had no evidence of the involvement of the ancient Egyptian state in the construction and maintenance of irrigation systems, and whenever he sought such evidence he turned to Mehmed Ali's Egypt (Wittfogel, 1963, p. 54)! It is obvious why it is illegitimate to extrapolate from modern 19th century Egypt to Middle Kingdom Egypt.

50 As Scott notes, "agriculturalists can exist and have existed independent of a larger state - anthropologists call such peoples 'primitives' - while it is not possible to imagine cities or noncultivating elites existing independently of the subordinate producing class by which they are sustained" (Scott, 1977c, p. 275).

51 This is not the only opposition that is expressed. There is also the expression of a lack of harmony between the cosmic and social levels, e.g., we also find the idea that the annual flood occurs, but there is no one to cultivate the land. Hence, the depiction of chaos at different levels also draws on the understanding of Maat as referring to both the cosmic and social orders. The general point that is being made is about the collapse of the harmony which existed between the cosmic and social order.

52 Note that in the following discussion I will be focusing on the argumentative structure of the text and not on the performative and formal aspects of the text. Christopher J. Eyre has provided an interesting account of the performative aspects of the tale, especially in relation to how different intonations in its reading would have influenced its reception by a listening audience (Eyre, 2000). The formal literary structure(s) of the text are examined in (Parkinson, 1992).

53 Although Schafick Allam argues that at least some of the passages which have been taken to refer to bureaucrats, are directed against "noblemen" who were the administrators of the High Steward's estate (Allam, 2000).

54 Note that strictly speaking the Egyptian metaphor is that of a herdsman, since Egyptian society was a cattle-rearing and not a sheep-rearing society (Karenga, 2004, p. 323). However, for the sake of convenience, most Egyptologists render it in terms of the more familiar biblical metaphor of a shepherd.

55 The shepherd metaphor was widely utilized in the ancient world. First in Mesopotamia, where it was widely used to depict the role of the king, and later on in the Greek world, where it was eventually rejected (Haubold, 2015). The limitations of the shepherd metaphor are not recognized by Jeffers in his analysis of The Tale of the Eloquent Peasant (2013), nor are they recognized by Karenga (2004, 323)

56 The king emphasized his relationship with the gods as opposed to his relationship with his subjects. In royal imagery his primary responsibility is to the gods and not to his human subjects. This was emphasized in royal imagery: "when royal largess is depicted in state-commissioned artwork, its subject is most often the king offering to the gods or showering golden baubles upon deserving nobles, rather than sharing royal larders with individuals in need. Clearly, then, the pharaoh did not promote himself primarily as man of and for the people, rather he more commonly boasted of his position as a man of and for the gods" (Morris, 2013, p. 60).

$57 \mathrm{My}$ aim here is not to produce an exhaustive account of all the metaphors for power and rulership that are deployed in The Tale of the Eloquent Peasant, for this cannot be done due to limitations of space. However, I hope to have demonstrated how we should analyze such metaphors. l.e., we should not simply ask whether they allow for criticisms of officials. They obviously do allow for that. The central question is whether they allow for criticisms of the discourse which justifies the social order as a whole. My contention is that they do not allow for that. However, in order to ascertain the truth of this hypothesis one would have to analyze all the metaphors for power and rulership that were used in ancient Egyptian discourse. My contention is that this is a fruitful research project which would contribute to explaining the relative stability of ancient Egyptian society during the Middle Kingdom.

58 Patronage networks seem to have played a more important role in ancient Egyptian society than was previously believed (Moreno Garcia, 2014, p. 253). 


\section{REFERENCES}

Abercrombie, N., \& Turner, B. S. (1978). The dominant ideology thesis. The British Journal of Sociology, 29(2), 149-170.

Allam, S. (2000). Social and legal aspects regarding the Trader from the Oasis. Lingua Aegyptia, 8, 83-92.

Allen, R. C. (1997). Agriculture and the origins of the state in ancient Egypt. Explorations in Economic History, 34, 135-154.

Althusser, L. (1971). Preface to Capital volume one. In B. Brewster (trans.), Lenin and philosophy and other essays. 1969. New York, NY: Monthly Review Press.

Amin, S. (1990). Colonialism and the rise of capitalism: A comment. Science \& Society, 54(1), 67-72.

Amin, S. (2009). Eurocentrism: Modernity, Religion, and Democracy. A Critique of Eurocentrism and Culturalism (2nd ed., R. Moore \& J. Membrez, Trans.). New York, NY: Monthly Review Press.

Assmann, J. (2002). The mind of Egypt: History and meaning in the time of the Pharaohs (A. Jenkins, Trans.). New York, NY: Metropolitan Books.

Babbitt, S. E. (2017). Epistemic and political freedom. In I. A. Kidd, J. Medina, \& G. Pohlhaus (Eds.), The Routledge handbook of epistemic injustice (pp. 261-269). London, UK: Routledge.

Baines, J. (1983). Literacy and ancient Egyptian society. Man, 18(3), 572-599.

Baines, J. (1990). Restricted knowledge, hierarchy, and decorum: Modern perceptions and ancient institutions. Journal of the American Research Center in Egypt, 27, 1-23.

Baines, J. (1995). Kingship, definition of culture, and legitimation. In D. O'Connor \& D. P. Silverman (Eds.), Ancient Egyptian kingship. Leiden, The Netherlands: Brill.

Baines, J. (2007). Visual and written culture in ancient Egypt. Oxford, UK: Oxford University Press.

Baines, J., \& Yoffee, N. (1998). Order, legitimacy, and wealth in ancient Egypt and Mesopotamia. In G. M. Feinman \& J. Marcus (Eds.), Archaic states (pp. 199-260). Santa Fe, NM: School of American Research Press.

Bárta, M. (2013). Egyptian kingship during the old kingdom. In J. A. Hill, P. Jones, \& A. J. Morales (Eds.), Experiencing power, generating authority: Cosmos, politics, and the ideology of kingship in ancient Egypt and Mesopotamia (pp. 257-284). Philadelphia, PA: University of Pennsylvania Museum of Archaeology and Anthropology.

Bellah, R. N. (2005). What is axial about the axial age? European Journal of Sociology, 46(1), 69-89.

Berger, P., \& Pullberg, S. (1965). Reification and the sociological critique of consciousness. History and Theory, 4(2), 196-211.

Bontty, M. (2000). Images of law and the disputing process in the Tale of the Eloquent Peasant. Lingua Aegyptia, 8, 93-107.

Boy, J. D., \& Torpey, J. (2013). Inventing the axial age: The origins and uses of a historical concept. Theory and Society, 42(3), 241-259.

Burawoy, M. (2012). The roots of domination: Beyond Bourdieu and Gramsci. Sociology, 46(2), 187-206.

Callender, G. (2000). The Middle Kingdom Renaissance (c.2055 - 1650 BC). In I. Shaw (Ed.), The Oxford history of ancient Egypt. Oxford, UK: Oxford University Press.

Carmona, S., \& Ezzamel, M. (2007). Accounting and accountability in ancient civilizations: Mesopotamia and ancient Egypt. Accounting, Auditing \& Accountability Journal, 20(2), 177-209.

Cox, R. (2017). Expanding the history of the just war: The ethics of war in ancient Egypt. International Studies Quarterly, 61, 371-384.

David, A. (2011). The Nmh and the paradox of the voiceless in the Eloquent Peasant. The Journal of Egyptian Archaeology, 97(1), 73-85.

David, R. (2002). Religion and magic in ancient Egypt. New York, NY: Penguin.

Driaux, D. (2020). Toward a study of the poor and poverty in ancient Egypt: Preliminary thoughts. Cambridge Archaeological Journal, 30(1), 1-19.

Drucker, H. M. (1972). Marx's concept of ideology. Philosophy, 47(180), 152-161.

Dunca, P. (2012). The perspective of analytic philosophy of religion on the almightiness of gods and the status of evil in the religions of the Ancient Near East, Egypt and Mesopotamia. European Journal of Science and Theology, 8(3), 27-35.

El Hassan, I. S. (1986). Consciousness and ideology: A critique of Lukács, Althusser and Poulantzas. Dialectical Anthropology, 11(1), 49-62.

El-Menshawy, S. (2014). Notes on the human characteristics of ancient Egyptian kings. Archiv Orientalni, 82, 411-430.

El Nabolsy, Z. (2019a). Listening. In D. R. Ford (Ed.), Keywords in radical philosophy and education: Common concepts for contemporary movements (pp. 255-270). Leiden, The Netherlands: Brill.

El Nabolsy, Z. (2019b). Aristotle on natural slavery: An analysis using the Marxist concept of ideology. Science \& Society, 83(2), 244-267.

Engels, F. (1966). The peasant war in Germany. New York, NY: International Publishers.

Engels, F. (2004). Engels to Franz Mehring July 141893 In Marx/Engels collected works Volume 50 Letters 1892-1895 (pp. 163-167). London, England: Lawrence and Wishart.

Eyerman, R. (1981). False consciousness and ideology. Acta Sociologica, 24(1/2), 43-58.

Eyre, C. J. (2000). The performance of the peasant. Lingua Aegyptia, 8, 9-25. 
Eyre, C. J. (2011). Patronage, power, and corruption in Pharaonic Egypt. International Journal of Public Administration, 34(11), 701-711.

Ezzamel, M. (2004). Work organization in the Middle Kingdom, ancient Egypt. Organization, 11(4), 497-537.

Fakhry, A. (2003). Bahriyah and Farafra (2nd ed.). Cairo, Egypt: The American University in Cairo Press.

Fricker, M. (2007). Epistemic injustice: Power and the ethics of knowing. Oxford, UK: Oxford University Press.

Garfinkle, S. J. (2013). Ancient near eastern city-states. In P. F. Bang \& W. Scheidel (Eds.), The Oxford handbook of the state in the ancient Near East and Mediterranean (pp. 94-119). Oxford, UK: Oxford University Press.

Gould, S. J. (1996). The mismeasure of man (2nd ed.). New York, NY: W.W Norton \& Company.

Gnirs, A. M. (2000). The language of corruption: On rich and poor in the Eloquent Peasant. Lingua Aegyptia, 8, $125-155$.

Grajetzki, W. (2006). The Middle Kingdom of Ancient Egypt. London, UK: Duckworth.

Graness, A. (2016). Writing the history of philosophy in Africa: Where to begin? Journal of African Cultural Studies, 28(2), 132-146.

Gutman, M. C. (1993). Rituals of resistance: A critique of the theory of everyday forms of resistance. Latin American Perspectives, 20(2), 74-92.

Jeffers, C. (2013). Embodying justice in ancient Egypt: The Tale of the Eloquent Peasant as a classic of political philosophy. British Journal for the History of Philosophy, 21(3), 421-442.

Haldon, J. (1993). The state and the tributary mode of production. London, UK: Verso.

Hare, T. (2000). The supplementarity of agency in the Eloquent Peasant. Lingua Aegyptia, 8, 1-7.

Haslanger, S. (2017). I-culture and critique. Aristotelian Society Supplementary Volume, 91(1), 149-173.

Haubold, J. (2015). Shepherds of the people: Greek and Mesopotamian discourses. In R. Rollinger \& E. van Dongen (Eds.), Mesopotamia in the ancient world: Impact, continuities, parallels (pp. 245-254). Münster, Germany: Ugarit-Verlag.

Hegel, G. W. F. (1969). Science of logic (A. V. Miller, Trans.). Atlantic Highlands, NJ: Humanities Press International, Inc.

Hegel, G. W. F. (1995). Lectures on the history of philosophy, Volume 1: Greek philosophy to Plato (E. S. Haldane, Trans.). Lincoln and London, UK: University of Nebraska Press.

Helmy, H. E. (2015). Smith on ancient Egypt and the Arab Islamic world: A tale of two statist models. Forum for Social Economics, 44(3), 251-283.

Hill, J. A., Jones, P., \& Morales, A. J. (2013). Introduction: Comparing kingship in ancient Egypt and Mesopotamia: Cosmos, politics and landscape. In J. A. Hill, P. Jones, \& A. J. Morales (Eds.), Experiencing power, generating authority: Cosmos, politics, and the ideology of kingship in ancient Egypt and Mesopotamia (pp. 2-32). Philadelphia, PA: University of Pennsylvania Museum of Archaeology and Anthropology.

Hornung, E. (1982). Conceptions of god in ancient Egypt: The one and the many (J. Baines, Trans.). Ithaca, NY: Cornell University Press.

Hunt, D. (1988). From the millennial to the everyday: James Scott's search for the essence of peasant politics. Radical History Review, 42, 155-172.

Ismail, M. (2009). Al-Muhamashoun fi Tarikh misr [The marginalized in Egypt's history]. Cairo, Egypt: Roueya.

Karenga, M. (2004). Maat, the moral ideal in ancient Egypt: A study in classical African ethics. London, UK: Routledge.

Kemp, B. J. (2006). Ancient Egypt: Anatomy of a civilization (2nd ed.). London, UK: Routledge.

Koning, H. (1976). Columbus: His enterprise, exploding the myth. New York, NY: Monthly Review Press.

Lacoste, Y. (1984). Ibn Khaldun: The birth of history and the past of the third world (D. Macey, Trans.). London, UK: Verso.

Lampert, J. (1995). Hegel and ancient Egypt: History and becoming. International Philosophical Quarterly, 34(1), 43-58.

Langer, C. (2015). The political realism of the Egyptian elite: A comparison between the Teaching for Merikare and Niccolò Machiavelli's II Principe. Journal of Egyptian History, 8, 49-79.

Leiter, B. (2015). Marx, law, ideology, legal positivism. Virginia Law Review, 101(4), 1179-1196.

Lehner, M. (2015). Labor and the pyramids: The Heit el-Ghurab 'workers town' at Giza. In P. Steinkeller \& M. Hudson (Eds.), Labor in the ancient world. Dresden, Germany: ISLET-Verlag.

Leprohon, R. J. (2015). Ideology and propaganda. In M. K. Hartwig (Ed.), A companion to ancient Egyptian art (pp. 309-327). Oxford, UK: Wiley-Blackwell.

Lerner, G. (1987). The creation of patriarchy. Oxford, UK: Oxford University Press.

Lichtheim, M. (2006). Ancient Egyptian literature, volume I: The Old and Middle Kingdoms. 1975. Berkeley, CA: University of California Press.

Light, M. A. (2000). The power of the law: Procedure as justice in the Eloquent Peasant. Lingua Aegyptia, 8, $109-124$.

Lloyd, A. B. (2013). Expeditions to the Wadi Hammamat: Context and concept. In J. A. Hill, P. Jones, \& A. J. Morales (Eds.), Experiencing power, generating authority: Cosmos, politics, and the ideology of kingship in ancient Egypt and Mesopotamia (pp. 361-382). Philadelphia, PA: University of Pennsylvania Museum of Archaeology and Anthropology.

Loprieno, A. (2000). Literature as mirror of social institutions: The case of the Eloquent Peasant. Lingua Aegyptia, 8, 183-198. 
Lorton, D. (1977). The treatment of criminals in ancient Egypt: Through the new kingdom. Journal of the Economic and Social History of the Orient, 20(1), 2-64.

Löwy, M. (1998). Friedrich Engels on religion and class struggle. Science \& Society, 62(1), 79-87.

Malek, J. (2000). The old kingdom (c. 2686 - 2160 BC). In I. Shaw (Ed.), The Oxford history of ancient Egypt (pp. 89-117). Oxford, UK: Oxford University Press.

Manning, J. G. (2012). The representation of justice in ancient Egypt. Yale Journal of Law \& Humanities, 24, 111-118.

Manning, J. G. (2013). Egypt. In P. F. Bang \& W. Scheidel (Eds.), The Oxford handbook of the state in the ancient Near East and Mediterranean (pp. 61-93) Oxford, UK: Oxford University Press.

Mannheim, K. (1960). Ideology and Utopia: An introduction to the sociology of knowledge (L. Wirth \& E. Shills, Trans.). London, UK: Routledge.

Marx, K. (1976). Capital: A critique of political economy (Vol. 1, B. Fowkes, Trans.). London, UK: Penguin.

Marx, K., \& Engels, F. (2013). The German ideology. New York, NY: International Publishers.

Medina, J. (2017). Varieties of hermeneutical injustice. In I. A. Kidd, J. Medina, \& G. Pohlhaus (Eds.), The Routledge handbook of epistemic injustice (pp. 41-52). London, UK: Routledge.

Miller, R. W. (1984). Analyzing Marx: Morality, power and history. Princeton, NJ: Princeton University Press.

Mills, C. W. (1986). Marxism and naturalistic mystification. Science \& Society, 49(4), 472-483.

Mills, C. W. (1989). Determination and consciousness in Marx. Canadian Journal of Philosophy, 19(3), 421-445.

Mills, C. W. (1994). Marxism, 'ideology' and moral objectivism. Canadian Journal of Philosophy, 24(3), 373-393.

Mills, C. W. (2005). Ideal theory as ideology. Hypatia, 20(3), 165-184.

Mills, C. W. (2017). Ideology. In I. A. Kidd, J. Medina, \& G. Pohlhaus (Eds.), The Routledge handbook of epistemic injustice (pp. 100-111). London, UK: Routledge.

Momigliano, A. (1975). Alien wisdom: The limits of hellenization. Cambridge, UK: Cambridge University Press.

Moreno Garcia, J. C. (2013). Building the Pharaonic state: Territory, elite, and power in ancient Egypt in the 3rd millennium BCE. In J. A. Hill, P. Jones, \& A. J. Morales (Eds.), Experiencing power, generating authority: Cosmos, politics, and the ideology of kingship in ancient Egypt and Mesopotamia (pp. 185-217). Philadelphia, PA: University of Pennsylvania Museum of Archaeology and Anthropology.

Moreno Garcia, J. C. (2014). Recent developments in the social and economic history of ancient Egypt. Journal of Ancient Near Eastern History, 1(2), 231-264.

Morenz, S. (1992). Egyptian religion (A. E. Keep, Trans.). Ithaca, NY: Cornell University Press.

Morenz, L. D. (2013). Texts before writing: Reading (proto-) Egyptian poetics of power. In J. A. Hill, P. Jones, \& A. J. Morales (Eds.), Experiencing power, generating authority: Cosmos, politics, and the ideology of kingship in ancient Egypt and Mesopotamia (pp. 121-150). Philadelphia, PA: University of Pennsylvania Museum of Archaeology and Anthropology.

Morris, E. (2013). Propaganda and performance at the dawn of the state. In J. A. Hill, P. Jones, \& A. J. Morales (Eds.), Experiencing power, generating authority: Cosmos, politics, and the ideology of kingship in ancient Egypt and Mesopotamia (pp. 33-64). Philadelphia, PA: University of Pennsylvania Museum of Archaeology and Anthropology.

Morris, E. (2018). Ancient Egyptian imperialism. Hoboken, NJ: Wiley-Blackwell.

Muhs, B. (2016). The ancient Egyptian economy: 3000 - 300 BCE. Oxford, UK: Oxford University Press.

Müller-Wollerman, R. (2015). Crime and punishment in Pharaonic Egypt. Near Eastern Archaeology, 78(4), $228-235$.

Nielsen, K. (1980). Marxism, ideology, and moral philosophy. Social Theory and Practice, 6(1), 53-68.

Obenga, T. (2004). Egypt: Ancient history of African philosophy. In K. Wiredu (Ed.), A companion to African philosophy (pp. 31-49). London, UK: Blackwell.

Oppenheim, A. (2015). Introduction: What was the Middle Kingdom?. In A. Oppenheim, D. Arnold, D. Arnold, \& K. Yamamoto (Eds.), Ancient Egypt transformed: The Middle Kingdom (pp. 1-8). New York, NY: The Metropolitan Museum of Art.

Parkinson, R. B. (1991). The date of the Eloquent Peasant. Revue D'Egyptologie, 42, 171-181.

Parkinson, R. B. (1992). Literary form and the Tale of the Eloquent Peasant. The Journal of Egyptian Archaeology, 78, 163-178.

Parkinson, R. B. (1997). The Tale of Sinuhe and other ancient Egyptian poems, 1940- 1640 BC. Oxford, UK: Oxford University Press (trans.).

Parkinson, R. B. (2000). Imposing words: The entrapment of language in the Tale of the Eloquent Peasant. Lingua Aegyptia, 8 , 27-51.

Parkinson, R. B. (2002). Poetry and culture in Middle Kingdom Egypt: A dark side to perfection. London, UK: Equinox.

Polanyi, K. (1957). Aristotle discovers the economy. In K. Polanyi, C. M. Arensberg, \& H. W. Pearson (Eds.), Trade and market in the early empires: Economies in history and theory. New York, NY: The Free Press.

Quirke, S. (1988). State and labour in the Middle Kingdom: A reconsideration of the term hnrt. Revue d'Egyptologie, 39 , 83-106.

Robins, G. (1993). Women in ancient Egypt. Cambridge, MA: Harvard University Press. 
Rosen, M. (1996). On voluntary servitude: False consciousness and the theory of ideology. Cambridge, MA: Harvard University Press.

Scott, J. C. (1977a). Protest and profanation: Agrarian revolt and the little tradition, part I. Theory and Society, 4(1), 1-38.

Scott, J. C. (1977b). Protest and profanation: Agrarian revolt and the little tradition, part II. Theory and Society, 4(2), 211-246.

Scott, J. C. (1977c). Hegemony and the peasantry. Politics \& Society, 7(3), 267-296.

Scott, J. C. (1989). Everyday forms of resistance. Copenhagen Papers in East and Southeast Asian Studies, 4, 33-62.

Seidlmayer, S. (2000). The first intermediate period (c.2160-2055 BC). In I. Shaw (Ed.), The Oxford history of ancient Egypt (pp. 118-147). Oxford, UK: Oxford University Press.

Silver, M. (2009). What makes shabti slave? Journal of the Economic and Social History of the Orient, 52(4/5), 619-634.

Sheehan, H. (2017). Marxism and the philosophy of science: A critical history. 1985. (2nd ed.). London, UK: Verso.

Shupak, N. (1992). A new source for the study of the judiciary and law of ancient Egypt: The Tale of the Eloquent Peasant. Journal of Near Eastern Studies, 51(1), 1-18.

Smith, M. E. (2004). The archaeology of ancient state economies. Annual Review of Anthropology, 33, 73-102.

Szacki, J. (1966). Remarks on the Marxian concept of false consciousness. The Polish Sociological Bulletin, 14, 30-39.

Thériault, C. A. (1993). The Instruction of Amenemhet as propaganda. Journal of the American Research Center in Egypt, 30, $151-160$.

Trigger, B. G. (1993). Early civilizations: Ancient Egypt in context. Cairo, Egypt: The American University Press in Cairo.

Trigger, B. G. (2003). Understanding early civilization: A comparative study. Cambridge, UK: Cambridge University Press.

Trigger, B. G., Kemp, B. J., O'Connor, D., \& Lloyd, A. B. (1983). Ancient Egypt: A social history. Cambridge, UK: Cambridge University Press.

Tyldesley, J. (1994). Daughters of Isis: Women of ancient Egypt. New York, NY: Penguin Books.

Urbainczyk, T. (2008). Slave revolts in antiquity. Berkley, MI/Los Angeles, CA: University of California Press.

Van de Mieroop, M. (2016). A history of the ancient Near East, ca 3000-323 BC (3rd ed.). Hoboken, NJ: Wiley-Blackwell.

Warburton, D. A. (2005). Working. In D. C. Snell (Ed.), A companion to the ancient Near East. London, UK: Blackwell Publishing.

Warburton, D. A. (2007). Work and compensation in ancient Egypt. The Journal of Egyptian Archaeology, 93, 175-194.

West, G. (2011). Tracking an ancient near eastern economic system: The tributary mode of production and the templestate. Old Testament Essays, 24(2), 511-532.

Willems, H. (2014). Historical and archaeological aspects of Egyptian funerary culture: Religious ideas and ritual practice in Middle Kingdom elite cemeteries. Leiden, The Netherlands: Brill.

Wittfogel, K. (1963). Oriental despotism: A comparative study of total power. New Haven, CT: Yale University Press.

Wood, A. (2004). Karl Marx (2nd ed.). New York, NY: Routledge.

Wolf, E. R. (1987). The Peasant War in Germany: Friedrich Engels as social historian. Science \& Society, 51(1), 82-92.

Zingarelli, A. (2015). Asiatic mode of production: Considerations on ancient Egypt. In L. de Garca \& A. Zingarelli (Eds.), Studies on pre-capitalist modes of production (pp. 27-76). Leiden, The Netherlands: Brill.

How to cite this article: Nabolsy Z. Using the Concepts of Hermeneutical Injustice and Ideology to Explain the Stability of Ancient Egypt During the Middle Kingdom. J Hist Sociol. 2020;1-26. https://doi.org/10.1111/ johs.12287 